\title{
2012 ACCF/AHA/HRS focused update of the 2008 guidelines for device-based therapy of cardiac rhythm abnormalities
}

A report of the American College of Cardiology Foundation/American Heart Association Task Force on Practice Guidelines

Developed in collaboration with The American Association for Thoracic Surgery, Heart Failure Society of America, and Society of Thoracic Surgeons

2012 Cynthia M. Tracy, MD, FACC, FAHA, Chair, ${ }^{*}$ Andrew E. Epstein, MD, FACC, FAHA, FHRS, Writing Vice Chair, ${ }^{*}$ Dawood Darbar, MD, FACC, FHRS ${ }^{\dagger}$ John P. DiMarco, MD, PhD, FACC, FHRS, $*, \ddagger$ Group Sandra B. Dunbar, RN, DSN, FAAN, FAHA ${ }^{\dagger}$ N. A. Mark Estes III, MD, FACC, FAHA, FHRS, ${ }^{*}, \S$ Members*: $\quad$ T. Bruce Ferguson, Jr, MD, FACC, FAHA, ${ }^{*}, \|,{ }^{\oplus}$ Stephen C. Hammill, MD, FACC, FHRS, ${ }^{\ddagger}$ Pamela E. Karasik, MD, FACC, FHRS ${ }^{\dagger}$ Mark S. Link, MD, FACC, FHRS, ${ }^{*}, \dagger$ Joseph E. Marine, MD, FACC, FHRS ${ }^{\dagger}$ Mark H. Schoenfeld, MD, FACC, FAHA, FHRS, ${ }^{*}$, Amit J. Shanker, MD, FACC, FHRS, ${ }^{\ddagger}$ Michael J. Silka, MD, FACC, ${ }^{\dagger}$ Lynne Warner Stevenson, MD, FACC, ${ }^{*}, \#$ William G. Stevenson, MD, FACC, FAHA, FHRS, ${ }^{* * *}$ and Paul D. Varosy, MD, FACC, FHRS ${ }^{\dagger}$

2008 Andrew E. Epstein, MD, FACC, FAHA, FHRS, Chair, John P. DiMarco, MD, PhD, FACC, Writing FHRS, Kenneth A. Ellenbogen, MD, FACC, FAHA, FHRS, N. A. Mark Estes III, MD, FACC, Committee FAHA, FHRS, Roger A. Freedman, MD, FACC, FHRS, Leonard S. Gettes, MD, FACC, FAHA, Members: A. Marc Gillinov, MD, FACC, FAHA, Gabriel Gregoratos, MD, FACC, FAHA, Stephen C. Hammill, MD, FACC, FHRS, David L. Hayes, MD, FACC, FAHA, FHRS, Mark A. Hlatky, MD, FACC, FAHA, L. Kristin Newby, MD, FACC, FAHA, Richard L. Page, MD, FACC, FAHA, FHRS, Mark H. Schoenfeld, MD, FACC, FAHA, FHRS, Michael J. Silka, MD, FACC, Lynne Warner Stevenson, MD, FACC, and Michael O. Sweeney, MD, FACC

ACCF/AHA Jeffrey L. Anderson, MD, FACC, FAHA, Chair, Alice K. Jacobs, MD, FACC, FAHA, Immediate Task Force Past Chair, Jonathan L. Halperin, MD, FACC, FAHA, Chair-Elect, Nancy M. Albert, PhD, Members: $\quad$ CCNS, CCRN, Mark A. Creager, MD, FACC, FAHA, David DeMets, PhD, Steven M. Ettinger, MD, FACC, Robert A. Guyton, MD, FACC, Judith S. Hochman, MD, FACC, FAHA, Frederick G. Kushner, MD, FACC, FAHA, E. Magnus Ohman, MD, FACC, William Stevenson, MD, FACC, FAHA, and Clyde W. Yancy, MD, FACC, FAHA

f Supplemental material is available online.

\footnotetext{
*Writing group members are required to recuse themselves from voting on sections to which their specific relationships with industry and other entities may apply; see Appendix 1 for recusal information. ${ }^{\dagger} \mathrm{ACCF} / \mathrm{AHA}$ Representative. ${ }^{\dagger} \mathrm{Heart}$ Rhythm Society Representative. ${ }^{\S}$ ACCF/AHA Task Force on Performance Measures Liaison. "American Association for Thoracic Surgery Representative. "Society of Thoracic Surgeons Representative. " Heart Failure Society of America Representative. ***ACCF/AHA Task Force on Practice Guidelines Liaison.

This document was approved by the American College of Cardiology Foundation Board of Trustees, the American Heart Association Science Advisory and Coordinating Committee, and the Heart Rhythm Society Board of Trustees in May 2012. The American College of Cardiology Foundation requests that this document be cited as follows: Tracy CM, Epstein AE, Darbar D, DiMarco JP, Dunbar SB, Estes NAM III, Ferguson TB Jr, Hammill SC, Karasik PE, Link MS, Marine JE, Schoenfeld MH, Shanker AJ, Silka MJ, Stevenson LW, Stevenson WG, Varosy PD. 2012 ACCF/AHA/HRS focused update of the 2008 guidelines for device-based therapy of cardiac rhythm abnormalities: a report of the American College of Cardiology Foundation/American Heart Association Task Force on Practice Guidelines. J Thorac Cardiovasc Surg. 2012;144:e127-45.
}

This article is copublished in Circulation, Heart Rhythm, and Journal of the American College of Cardiology.

Copies: This document is available on the World Wide Web sites of the American College of Cardiology (www.cardiosource.org), the American Heart Association (my.americanheart.org), and the Heart Rhythm Society (www.hrsonline.org). For copies of this document, please contact Elsevier Inc. Reprint Department, fax (212) 633-3820, E-mail reprints@elsevier.com.

Permissions: Multiple copies, modification, alteration, enhancement, and/or distribution of this document are not permitted without the express permission of the American College of Cardiology Foundation. Please contact Elsevier's permission department at healthpermissions@elsevier.com.

0022-5223/ $\$ 36.00$

Copyright (C) 2012 by The American Association for Thoracic Surgery, the American College of Cardiology Foundation, the American Heart Association, Inc, and the Heart Rhythm Society.

http://dx.doi.org/10.1016/j.jtcvs.2012.08.032 


\section{TABLE OF CONTENTS}

Preamble . . . . . . . . . . . . . . . . . . . . . . .e128

1. Introduction $\ldots \ldots \ldots \ldots \ldots \ldots \ldots \ldots \ldots \ldots \ldots$.e130

1.1. Methodology and Evidence Review ..... . . . . . e130

1.2. Organization of the Writing Group . . . . . . . . . e131

1.3. Document Review and Approval . . . . . . . . . . e131

1.4. Scope of the Focused Update . . . . . . . . . . e131

2. Indications for Pacing . . . . . . . . . . . . e132

2.4. Pacing for Hemodynamic Indications . . . . . . . . . e132

2.4.1. Cardiac Resynchronization Therapy ... . . e132

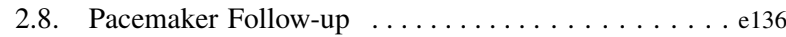

2.8.3. Remote Follow-up and Monitoring .... . .e136

Presidents and Staff . . . . . . . . . . . . . . . . . . .e137

References ................ . . . . . . . . . . . . e137

Appendix 1 Author relationships with industry and other

entities (relevant)—2012 ACCF/AHA/HRS

focused update of the 2008 guidelines for

device-based therapy of cardiac rhythm

abnormalities ..................e140

Appendix 2 Reviewer relationships with industry and other entities (relevant)—2012 ACCF/AHA/HRS

focused update of the 2008 guidelines for device-based therapy of cardiac rhythm

abnormalities ................... 142

Appendix 3 Indications for CRT therapy—algorithm . . .e145

\section{PREAMBLE}

Keeping pace with the stream of new data and evolving evidence on which guideline recommendations are based is an ongoing challenge to timely development of clinical practice guidelines. In an effort to respond promptly to new evidence, the American College of Cardiology Foundation (ACCF)/American Heart Association (AHA) Task Force on Practice Guidelines (Task Force) has created a "focused update" process to revise the existing guideline recommendations that are affected by evolving data or opinion. New evidence is reviewed in an ongoing fashion to more efficiently respond to important science and treatment trends that could have a major impact on patient outcomes and quality of care. Evidence is reviewed at least twice a year, and updates are initiated on an as-needed basis and completed as quickly as possible while maintaining the rigorous methodology that the ACCF and AHA have developed during their partnership of $>20$ years.

These focused updates are prompted following a thorough review of late-breaking clinical trials presented at national and international meetings, in addition to other new published data deemed to have an impact on patient care (Section 1.1, "Methodology and Evidence Review"). Through a broad-based vetting process, the studies included are identified as being important to the relevant patient population. The focused update is not intended to be based on a complete literature review from the date of the previous guideline publication but rather to include pivotal new evidence that may affect changes to current recommendations.

Specific criteria or considerations for inclusion of new data include the following:

- publication in a peer-reviewed journal;

- large, randomized, placebo-controlled trial(s);

- nonrandomized data deemed important on the basis of results affecting current safety and efficacy assumptions, including observational studies and metaanalyses;

- strength/weakness of research methodology and findings;

- likelihood of additional studies influencing current findings;

- impact on current and/or likelihood of need to develop new performance measure(s);

- request(s) and requirement(s) for review and update from the practice community, key stakeholders, and other sources free of industry relationships or other potential bias;

- number of previous trials showing consistent results; and

- need for consistency with a new guideline or guideline updates or revisions.

In analyzing the data and developing recommendations and supporting text, the writing group uses evidencebased methodologies developed by the Task Force. ${ }^{1}$ The Class of Recommendation (COR) is an estimate of the size of the treatment effect, with consideration given to risks versus benefits, as well as evidence and/or agreement that a given treatment or procedure is or is not useful/effective and in some situations may cause harm. The Level of Evidence (LOE) is an estimate of the certainty or precision of the treatment effect. The writing group reviews and ranks evidence supporting each recommendation, with the weight of evidence ranked as LOE A, B, or C, according to specific definitions that are included in Table 1. Studies are identified as observational, retrospective, prospective, or randomized, as appropriate. For certain conditions for which inadequate data are available, recommendations are based on expert consensus and clinical experience and are ranked as LOE C. When recommendations at LOE C are supported by historical clinical data, appropriate references (including clinical reviews) are cited if available. For issues for which sparse data are available, a survey of current practice among the clinicians on the writing group is the basis for LOE C recommendations, and no references are cited. The schema for COR and LOE is summarized in Table 1, which also provides suggested phrases for writing recommendations within each COR. A new addition to this methodology is separation of the Class III recommendations to delineate whether the recommendation is determined to be of "no benefit" or is associated with "harm" to the patient. In addition, in view of the increasing number of comparative effectiveness studies, comparator verbs and suggested phrases for writing recommendations for the comparative 
TABLE 1. Applying classification of recommendations and level of evidence

SIZE OF TREATMENT EFFECT

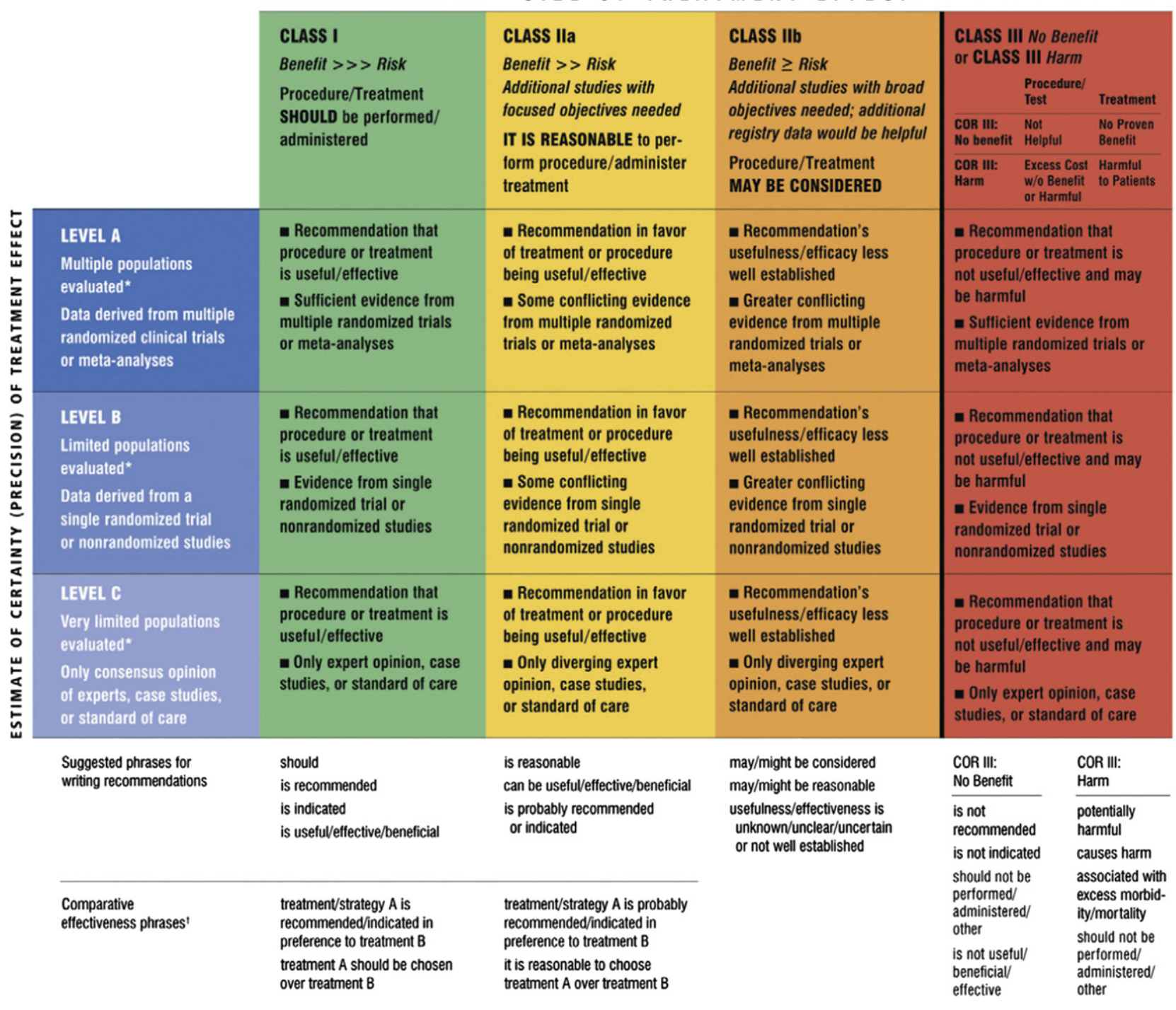

A recommendation with Level of Evidence B or C does not imply that the recommendation is weak. Many important clinical questions addressed in the guidelines do not lend themselves to clinical trials. Although randomized trials are unavailable, there may be a very clear clinical consensus that a particular test or therapy is useful or effective. *Data available from clinical trials or registries about the usefulness/efficacy in different subpopulations, such as sex, age, history of diabetes, history of prior myocardial infarction, history of heart failure, and prior aspirin use. †For comparative effectiveness recommendations (Class I and IIa; Level of Evidence A and B only), studies that support the use of comparator verbs should involve direct comparisons of the treatments or strategies being evaluated.

effectiveness of one treatment or strategy versus another have been added for COR I and IIa, LOE A or B only.

In view of the advances in medical therapy across the spectrum of cardiovascular diseases, the Task Force has designated the term guideline-directed medical therapy (GDMT) to represent optimal medical therapy as defined by ACCF/AHA guideline (primarily Class I)-recommended therapies. This new term, GDMT, will be used herein and throughout all future guidelines.

Because the ACCF/AHA practice guidelines address patient populations (and health care providers) residing in
North America, drugs that are not currently available in North America are discussed in the text without a specific COR. For studies performed in large numbers of subjects outside North America, each writing group reviews the potential impact of different practice patterns and patient populations on the treatment effect and relevance to the ACCF/ AHA target population to determine whether the findings should inform a specific recommendation.

The ACCF/AHA practice guidelines are intended to assist health care providers in clinical decision making by describing a range of generally acceptable approaches to the 
diagnosis, management, and prevention of specific diseases or conditions. The guidelines attempt to define practices that meet the needs of most patients in most circumstances. The ultimate judgment about care of a particular patient must be made by the health care provider and patient in light of all the circumstances presented by that patient. As a result, situations may arise in which deviations from these guidelines may be appropriate. Clinical decision making should consider the quality and availability of expertise in the area where care is provided. When these guidelines are used as the basis for regulatory or payer decisions, the goal should be improvement in quality of care. The Task Force recognizes that situations arise in which additional data are needed to inform patient care more effectively; these areas will be identified within each respective guideline when appropriate.

Prescribed courses of treatment in accordance with these recommendations are effective only if they are followed. Because lack of patient understanding and adherence may adversely affect outcomes, physicians and other health care providers should make every effort to engage the patient's active participation in prescribed medical regimens and lifestyles. In addition, patients should be informed of the risks, benefits, and alternatives to a particular treatment and should be involved in shared decision making whenever feasible, particularly for COR IIa and IIb, for which the benefit-to-risk ratio may be lower.

The Task Force makes every effort to avoid actual, potential, or perceived conflicts of interest that may arise as a result of industry relationships or personal interests among the members of the writing group. All writing group members and peer reviewers of the guideline are required to disclose all current health care-related relationships, including those existing 12 months before initiation of the writing effort. In December 2009, the ACCF and AHA implemented a new policy for relationships with industry and other entities (RWI) that requires the writing group chair plus a minimum of $50 \%$ of the writing group to have no relevant RWI (Appendix 1 includes the ACCF/AHA definition of relevance). These statements are reviewed by the Task Force and all members during each conference call and/or meeting of the writing group and are updated as changes occur. All guideline recommendations require a confidential vote by the writing group and must be approved by a consensus of the voting members. Members are not permitted to draft or vote on any text or recommendations pertaining to their RWI. Members who recused themselves from voting are indicated in the list of writing group members, and specific section recusals are noted in Appendix 1. Authors' and peer reviewers' RWI pertinent to this guideline are disclosed in Appendices 1 and 2, respectively. Additionally, to ensure complete transparency, writing group members' comprehensive disclosure information-including RWI not pertinent to this document-is available as an online supplement. Comprehensive disclosure information for the Task Force is also available online at www. cardiosource.org/ACC/About-ACC/Leadership/Guidelinesand-Documents-Task-Forces.aspx. The work of the writing group is supported exclusively by the ACCF, AHA, and the Heart Rhythm Society (HRS) without commercial support. Writing group members volunteered their time for this activity.

In an effort to maintain relevance at the point of care for practicing physicians, the Task Force continues to oversee an ongoing process improvement initiative. As a result, in response to pilot projects, several changes to these guidelines will be apparent, including limited narrative text, a focus on summary and evidence tables (with references linked to abstracts in PubMed), and more liberal use of summary recommendation tables (with references that support LOE) to serve as a quick reference.

In April 2011, the Institute of Medicine released 2 reports: Finding What Works in Health Care: Standards for Systematic Reviews and Clinical Practice Guidelines We Can Trust. $^{2,3}$ It is noteworthy that the ACCF/AHA practice guidelines were cited as being compliant with many of the standards that were proposed. A thorough review of these reports and our current methodology is under way, with further enhancements anticipated.

The recommendations in this focused update are considered current until they are superseded in another focused update or the full-text guideline is revised. Guidelines are official policy of both the ACCF and AHA.

Jeffrey L. Anderson, MD, FACC, FAHA

Chair, ACCF/AHA Task Force on Practice Guidelines

\section{INTRODUCTION}

\subsection{Methodology and Evidence Review}

Late-breaking clinical trials presented at the annual scientific meetings of the ACC, AHA, HRS, and European Society of Cardiology (2008 through 2010), as well as other selected data reported through January 2012, were reviewed by the guideline writing group along with the Task Force and other experts to identify trials and other key data that might affect guideline recommendations. On the basis of the criteria and considerations noted previously (Preamble), recently published trial data and other clinical information were considered important enough to prompt a focused update of the "ACC/AHA/HRS 2008 Guidelines for DeviceBased Therapy of Cardiac Rhythm Abnormalities.",

To provide clinicians with a comprehensive set of data, the absolute risk difference and number needed to treat or harm, if they were published and their inclusion was deemed appropriate, are provided in the guideline, along with confidence intervals (CIs) and data related to the relative treatment effects, such as odds ratio, relative risk (RR), hazard ratio (HR), or incidence rate ratio. 
Consult the full-text version of the "ACC/AHA/HRS 2008 Guidelines for Device-Based Therapy of Cardiac Rhythm Abnormalities" for policy on clinical areas not covered by the focused update. ${ }^{4}$ The individual recommendations in this focused update will be incorporated into future revisions or updates of the full-text guideline.

\subsection{Organization of the Writing Group}

For this focused update, selected members of the 2008 Device-Based Therapy (DBT) Writing Committee were invited to participate on the basis of areas of expertise, requirements for committee rotation, and the current RWI policy; those who agreed are referred to as the 2012 Focused Update Writing Group. The HRS was invited to be a partner on this focused update and has provided representation. The writing group also included representatives from the American Association for Thoracic Surgery, Heart Failure Society of America, and Society of Thoracic Surgeons.

\subsection{Document Review and Approval}

This document was reviewed by 2 official reviewers each nominated by the ACCF, AHA, and HRS, as well as 1 reviewer each from the American Association for Thoracic Surgery, Heart Failure Society of America, and Society of Thoracic Surgeons, and 21 individual content reviewers. All information on reviewers' RWI was collected and distributed to the writing group and is published in this document (Appendix 2).

This document was approved for publication by the governing bodies of the ACCF, AHA, and HRS and was endorsed by the American Association for Thoracic Surgery, Heart Failure Society of America, and Society of Thoracic Surgeons.

\subsection{Scope of the Focused Update}

Studies relevant to the management of patients treated with DBT for cardiac rhythm abnormalities were identified and reviewed as described previously in Section 1.1, "Methodology and Evidence Review." On the basis of these data, the writing group determined that updates to the 2008 guideline were necessary for cardiac resynchronization therapy (CRT) and device follow-up.

Many clinical circumstances come into question in daily practice as to the appropriate use of implantable cardioverter-defibrillator (ICD)/CRT devices. Many of these clinical scenarios are both common and of great importance but have not or cannot be addressed by multicenter clinical trials, so many of these will be addressed in the "Appropriate Use Criteria (AUC) for Implantable Cardioverter-Defibrillators and Cardiac Resynchronization Therapy" document that is currently in development. Unlike comprehensive guidelines, AUC documents blend evidence-based information and clinical experience that can help guide allocation of health care resources, and they focus on the most common patient scenarios for which procedures may be considered. The AUC document will help define when it is reasonable to perform a procedure and, importantly, when it is not reasonable. Some of the scenarios included in the AUC may be outside guideline indications. As such, AUC are complementary to guidelines and should be used in conjunction with them for determining patient care. Furthermore, the ACCF and AHA are currently undertaking a revision of the guidelines for management of heart failure (HF). The DBT and HF guideline writing committees have worked to maintain concordance on the recommendations with regard to indications for CRT.

The writing group also thoroughly reviewed the following sections from the 2008 DBT guideline ${ }^{4}$ and determined that although some new information may be available, the recommendations remain current.

1. Hypertrophic cardiomyopathy-The management of hypertrophic cardiomyopathy is addressed in the "2011 ACCF/AHA Guideline for the Diagnosis and Treatment of Hypertrophic Cardiomyopathy." 5 In that document, the indications for ICDs have been modified on the basis of reassessment of significance of risk factors. The present writing group did not analyze the source documents that led to these changes and refer the reader to the ACCF/AHA Guideline for full discussion of ICDs in hypertrophic cardiomyopathy.

2. Arrhythmogenic right ventricular dysplasia/cardiomyopathy-The writing group reviewed all published evidence since the publication of the 2008 DBT guideline related to arrhythmogenic right ventricular dysplasia/cardiomyopathy and determined that no changes to the current recommendations for ICD indications were warranted.

3. Genetic arrhythmia syndromes-The writing group acknowledges that recent guidelines and data suggest that there may be a limited role for primary-prevention ICDs in individuals with a genetically confirmed diagnosis of long QT but without symptoms. ${ }^{6-8}$ Nevertheless, it is the consensus of this writing group that until more definitive trials or studies are completed, further refinement of criteria for ICD implantation in this patient group would not be appropriate. Therefore, the class of recommendations for ICD implantation in asymptomatic patients with a genetically confirmed mutation will remain unchanged.

4. Congenital heart disease-As with other forms of structural heart disease, there has been increased use of ICDs for primary prevention of sudden cardiac death in patients with congenital heart disease. ${ }^{4,9}$ Although randomized clinical trials have not been performed, multiple observational studies have consistently reported that systemic ventricular dysfunction in patients with 
congenital heart disease is the risk factor most predictive of subsequent sudden cardiac death or appropriate ICD rescue. ${ }^{10-12}$ These studies support consideration of an expanded role of ICDs in future revisions of the guideline, provided that consistent benefit with the use of ICDs in patients with congenital heart disease and advanced ventricular dysfunction is demonstrated. Nevertheless, the current recommendations are not changed at this time. There remain insufficient data to make specific recommendations about CRT in patients with congenital heart disease. ${ }^{13}$

5. Primary electrical disease-The writing group reviewed all published evidence since the publication of the 2008 DBT guideline related to primary electrical disease and determined that no changes were warranted in the current recommendations for ICD indications with regard to idiopathic ventricular fibrillation, short-QT syndrome, Brugada syndrome, and catecholaminergic polymorphic ventricular tachycardia.

6. Terminal care-Patients with cardiovascular implantable electronic devices (CIEDs) are living longer, with more surviving to develop comorbid conditions such as dementia or malignancy that may ultimately define their clinical course. This was recognized in the terminal care section of the 2008 DBT guideline. Recommendations on management of CIEDs in patients nearing end of life or requesting withdrawal of therapy were expanded upon in 2 subsequent HRS expert consensus statements in an effort to provide guidance to caregivers dealing with this increasingly prevalent and difficult issue. ${ }^{14,15}$

\section{INDICATIONS FOR PACING}

\subsection{Pacing for Hemodynamic Indications}

Although most commonly used to treat or prevent abnormal rhythms, pacing can alter the activation sequence in the paced chambers, influencing regional contractility and hemodynamics. These changes are frequently insignificant clinically but can be beneficial or harmful in some conditions. Pacing to decrease symptoms for patients with obstructive hypertrophic cardiomyopathy is discussed separately in the full-text guideline, Section 2.4.2, "Obstructive Hypertrophic Cardiomyopathy."

\subsubsection{Cardiac Resynchronization Therapy}

(See Table 2 and the Online Data Supplement for additional data on the trials that comprise the basis for the recommendations in this focused update.)

The present document proposes several changes in recommendations for CRT, compared with the 2008 document. The most significant changes are (1) limitation of the Class I indication to patients with QRS duration $\geq 150 \mathrm{~ms}$; (2) limitation of the Class I indication to patients with left bundle-branch block (LBBB) pattern; (3) expansion of
Class I indication to New York Heart Association (NYHA) class II (and with LBBB with QRS duration $\geq 150 \mathrm{~ms}$ ); and (4) the addition of a Class IIb recommendation for patients who have left ventricular ejection fraction (LVEF) $\leq 30 \%$, ischemic etiology of $\mathrm{HF}$, sinus rhythm, LBBB with a QRS duration $\geq 150 \mathrm{~ms}$, and NYHA class I symptoms. These changes may have important implications for patient selection in clinical practice, and the justification for these changes is discussed in the following paragraphs.

Progression of left ventricular (LV) systolic dysfunction to clinical HF is frequently accompanied by impaired electromechanical coupling, which may further diminish effective ventricular contractility. The most common disruptions are prolonged atrioventricular conduction (first-degree atrioventricular block) and prolonged interventricular conduction, most commonly LBBB. Prolonged interventricular and intraventricular conduction causes regional mechanical delay within the left ventricle that can result in reduced ventricular systolic function, altered myocardial metabolism, functional mitral regurgitation, and adverse remodeling with ventricular dilatation. ${ }^{31}$ Prolongation of the QRS duration occurs in approximately one third of patients with advanced $\mathrm{HF}^{32,33}$ and has been associated with ventricular electromechanical delay ("dyssynchrony"), as identified by multiple sophisticated echocardiographic indices. QRS duration and dyssynchrony both have been identified as predictors of worsening $\mathrm{HF}$, sudden cardiac death, and total death. ${ }^{34}$

Modification of ventricular electromechanical delay with multisite ventricular pacing (commonly called "biventricular pacing" or CRT) can improve ventricular systolic function, reduce metabolic costs, ameliorate functional mitral regurgitation, and, in some patients, induce favorable remodeling with reduction of cardiac chamber dimensions. ${ }^{35-37}$ Functional improvement has been demonstrated for exercise capacity, with peak oxygen consumption in the range of 1 to $2 \mathrm{~mL} / \mathrm{kg} / \mathrm{min}$ and a 50 - to 70-meter increase in 6-minute walking distance, as well as a 10-point or greater reduction of HF symptoms on the 105-point Minnesota Living with Heart Failure scale. ${ }^{16,38,39}$

Meta-analyses of initial clinical experiences and larger subsequent trials of CRT confirmed an approximately $30 \%$ decrease in hospitalizations and a mortality rate benefit of $24 \%$ to $36 \%{ }^{40}$ In the COMPANION (Comparison of Medical Therapy, Pacing, and Defibrillation in Heart Failure) trial (NYHA class III/IV HF, QRS duration $>120$ $\mathrm{ms}$, and $\mathrm{LVEF} \leq 35 \%$ on GDMT), GDMT was compared to CRT pacing therapy without backup defibrillation (CRT-Pacemaker) and to CRT therapy with defibrillation backup (CRT-D). ${ }^{17}$ Both CRT-Pacemaker and CRT-D reduced the risk of the primary composite endpoint by approximately $20 \%$ as compared with GDMT alone. CRT-D reduced the mortality rate by $36 \%$ compared with medical therapy, but there was insufficient evidence to conclude that 
TABLE 2. Recommendations for CRT in patients with systolic heart failure

\begin{tabular}{|c|c|}
\hline 2012 DBT Focused Update Recommendations & Comments \\
\hline \multicolumn{2}{|l|}{ Class I } \\
\hline $\begin{array}{l}\text { 1. CRT is indicated for patients who have LVEF less than or equal to } 35 \% \text {, } \\
\text { sinus rhythm, LBBB with a QRS duration greater than or equal to } 150 \\
\text { ms, and NYHA class II, III, or ambulatory IV symptoms on GDMT. } \\
\text { (Level of Evidence: A for NYHA class III/IV }{ }^{16-19} ; \text { Level of Evidence: B } \\
\text { for NYHA class } I^{20,21} \text { ) }\end{array}$ & $\begin{array}{l}\text { Modified recommendation (specifying CRT in patients with LBBB of } \geq 150 \\
\text { ms; expanded to include those with NYHA class II symptoms). }\end{array}$ \\
\hline \multicolumn{2}{|l|}{ Class IIa } \\
\hline $\begin{array}{l}\text { 1. CRT can be useful for patients who have LVEF less than or equal to } \\
35 \% \text {, sinus rhythm, LBBB with a QRS duration } 120 \text { to } 149 \text { ms, and } \\
\text { NYHA class II, III, or ambulatory IV symptoms on GDMT. }{ }^{16-18,20-22} \\
\text { (Level of Evidence: } B \text { ) }\end{array}$ & New recommendation \\
\hline $\begin{array}{l}\text { 2. CRT can be useful for patients who have LVEF less than or equal to } \\
35 \% \text {, sinus rhythm, a non-LBBB pattern with a QRS duration greater } \\
\text { than or equal to } 150 \mathrm{~ms} \text {, and NYHA class III/ambulatory class IV } \\
\text { symptoms on GDMT. }{ }^{16-18,21} \text { (Level of Evidence: } A \text { ) }\end{array}$ & New recommendation \\
\hline $\begin{array}{l}\text { 3. CRT can be useful in patients with atrial fibrillation and LVEF less than } \\
\text { or equal to } 35 \% \text { on GDMT if a) the patient requires ventricular pacing } \\
\text { or otherwise meets CRT criteria and b) AV nodal ablation or } \\
\text { pharmacologic rate control will allow near } 100 \% \text { ventricular pacing } \\
\text { with CRT. }{ }^{23-26,26 a, 48} \text { (Level of Evidence: B) }\end{array}$ & $\begin{array}{l}\text { Modified recommendation (wording changed to indicate benefit based on } \\
\text { ejection fraction rather than NYHA class; level of evidence changed from } \\
\text { C to B). }\end{array}$ \\
\hline $\begin{array}{l}\text { 4. CRT can be useful for patients on GDMT who have LVEF less than or } \\
\text { equal to } 35 \% \text { and are undergoing new or replacement device } \\
\text { placement with anticipated requirement for significant }(>40 \%) \\
\text { ventricular pacing. }{ }^{25,27-29} \text { (Level of Evidence: } C \text { ) }\end{array}$ & $\begin{array}{l}\text { Modified recommendation (wording changed to indicate benefit based on } \\
\text { ejection fraction and need for pacing rather than NYHA class); class } \\
\text { changed from IIb to IIa). }\end{array}$ \\
\hline \multicolumn{2}{|l|}{ Class IIb } \\
\hline $\begin{array}{l}\text { 1. CRT may be considered for patients who have LVEF less than or equal } \\
\text { to } 30 \% \text {, ischemic etiology of heart failure, sinus rhythm, LBBB with } \\
\text { a QRS duration of greater than or equal to } 150 \mathrm{~ms} \text {, and NYHA class I } \\
\text { symptoms on GDMT. }{ }^{20,21} \text { (Level of Evidence: } C \text { ) }\end{array}$ & New recommendation \\
\hline $\begin{array}{l}\text { 2. CRT may be considered for patients who have LVEF less than or equal } \\
\text { to } 35 \% \text {, sinus rhythm, a non-LBBB pattern with QRS duration } 120 \text { to } \\
149 \mathrm{~ms} \text {, and NYHA class III/ambulatory class IV on GDMT. }{ }^{21,30} \text { (Level } \\
\text { of Evidence: } B \text { ) }\end{array}$ & New recommendation \\
\hline $\begin{array}{l}\text { 3. CRT may be considered for patients who have LVEF less than or equal } \\
\text { to } 35 \% \text {, sinus rhythm, a non-LBBB pattern with a QRS duration } \\
\text { greater than or equal to } 150 \mathrm{~ms} \text {, and NYHA class II symptoms on } \\
\text { GDMT. }^{20,21} \text { (Level of Evidence: B) }\end{array}$ & New recommendation \\
\hline \multicolumn{2}{|l|}{ Class III: No Benefit } \\
\hline $\begin{array}{l}\text { 1. CRT is not recommended for patients with NYHA class I or II } \\
\text { symptoms and non-LBBB pattern with QRS duration less than } 150 \\
\mathrm{~ms}^{20,21,30} \text { (Level of Evidence: } B \text { ) }\end{array}$ & New recommendation \\
\hline $\begin{array}{l}\text { 2. CRT is not indicated for patients whose comorbidities and/or frailty } \\
\text { limit survival with good functional capacity to less than } 1 \text { year. }{ }^{19} \text { (Level } \\
\text { of Evidence: } C \text { ) }\end{array}$ & $\begin{array}{l}\text { Modified recommendation (wording changed to include cardiac as well as } \\
\text { noncardiac comorbidities). }\end{array}$ \\
\hline
\end{tabular}

See Appendix 3, "Indications for CRT Therapy—Algorithm." CRT, Cardiac resynchronization therapy; $D B T$, device-based therapy; GDMT, guideline-directed medical therapy; $L B B B$, left bundle-branch block; $L V E F$, left ventricular ejection fraction; NYHA, New York Heart Association.

CRT-Pacemaker was inferior to CRT-D. The CARE-HF (Cardiac Resynchronization in Heart Failure) trial ${ }^{18}$ limited subjects to a QRS duration $>150 \mathrm{~ms}(89 \%$ of patients) or QRS duration 120 to $150 \mathrm{~ms}$ with echocardiographic evidence of dyssynchrony ( $11 \%$ of patients). It was the first study to show a significant $(36 \%)$ reduction in death rate for resynchronization therapy unaccompanied by backup defibrillation compared with GDMT. ${ }^{18}$
In the present document, we give a Class I recommendation for CRT in patients with QRS duration $\geq 150 \mathrm{~ms}$. The differential classification seen in this document related to QRS duration is based on the results of multiple analyses of CRT benefit. The prevalence of mechanical dyssynchrony has been documented in $>40 \%$ of patients with dilated cardiomyopathy and QRS duration $>120 \mathrm{~ms}$, and is as high as $70 \%$ among patients with QRS duration 
$>150 \mathrm{~ms}$ and intraventricular mechanical delay, as identified by several echocardiographic techniques. ${ }^{34,41}$ However, the aggregate clinical experience has consistently demonstrated that a significant clinical benefit from CRT is greatest among patients with QRS duration $>150 \mathrm{~ms} .^{42,43}$ In a meta-analysis of 5 trials involving 6501 patients, CRT significantly decreased the primary endpoint of death or hospitalization for HF in patients with QRS duration $\geq 150 \mathrm{~ms}$ (HR, 0.58; 95\% CI, 0.50 to 0.68 ; $P<.00001)$ but not in patients with QRS duration $<150$ ms (HR, $0.95 ; 95 \%$ CI, 0.83 to $1.10 ; P=.51) .{ }^{42}$ In addition, subgroup analyses from several studies have suggested that a QRS duration $<150 \mathrm{~ms}$ is a risk factor for failure to respond to CRT therapy. ${ }^{43,44}$ The observed differential benefit of CRT was seen across patients in NYHA classes I through IV. It has not been possible to reliably identify those with shorter QRS durations who may benefit. Patients with shorter QRS durations who otherwise qualify for CRT are afforded Class II recommendations in these guidelines.

An additional difference in the present document compared with the 2008 DBT guideline ${ }^{4}$ is the limitation of the recommendation for Class I indication to patients with LBBB pattern as compared to those with non-LBBB. For patients with $\mathrm{QRS}$ duration $\geq 120 \mathrm{~ms}$ who do not have a complete LBBB (non-LBBB patterns), evidence for benefit with CRT is less compelling than in the presence of LBBB. ${ }^{45-47}$ The impact of the specific QRS morphology on clinical event reduction with CRT was evaluated in a meta-analysis of 4 clinical trials including 5356 patients. ${ }^{43}$ In those with LBBB, CRT significantly reduced composite adverse clinical events (RR, 0.64; 95\% CI, 0.52 to 0.77 ; $P=.00001)$. No benefit was observed for patients with non-LBBB conduction abnormalities (RR, 0.97; 95\% CI, 0.82 to $1.15 ; P=.75$ ). Specifically, there was no benefit in patients with right bundle-branch block (RR, 0.91; $95 \% \mathrm{CI}, 0.69$ to $1.20 ; P=.49$ ) or nonspecific intraventricular conduction delay (RR, $1.19 ; 95 \% \mathrm{CI}, 0.87$ to 1.63 ; $P=.28)$. Overall, the difference in effect of CRT between LBBB versus non-LBBB patients was highly statistically significant $(P=.0001){ }^{43}$ Nevertheless, other studies have shown that CRT is more likely to be effective in patients with advanced HF and non-LBBB morphologies if they have a markedly prolonged QRS duration ${ }^{21,30}$ (see RAFT [Resynchronization-Defibrillation for Ambulatory Heart Failure Trial] ${ }^{21}$ discussion below). Furthermore, patients with QRS prolongation due to frequent right ventricular apical pacing may benefit from CRT when other criteria for CRT are met. ${ }^{23,25,48}$ No large trial has yet demonstrated clinical benefit among patients without QRS prolongation, even when they have been selected with echocardiographic measures of dyssynchrony. ${ }^{49}$

The observed heterogeneity of response even among those who would appear to be excellent candidates for
CRT also may result from factors such as suboptimal lead location and the location of conduction block from fibrosis in relation to the pacing site. Several recent studies have emphasized the importance of LV lead placement. For example, wider LV-right ventricular lead separation has been shown to provide better results. ${ }^{50}$ A subanalysis of MADIT-CRT (Multicenter Automatic Defibrillator Implantation Trial with Cardiac Resynchronization Therapy) ${ }^{20}$ showed that an apical LV lead position, as compared with a basal or midventricular position, resulted in a significant increased risk for HF or death. ${ }^{51}$

Clinical trials of resynchronization included mainly patients in sinus rhythm. However, prospective experience among patients with permanent atrial fibrillation and with decreased LV systolic function suggests that benefit may result from biventricular pacing when the QRS duration is $>120 \mathrm{~ms}$, although it may be most evident in patients in whom atrioventricular nodal ablation has been performed, such that right ventricular pacing is obligate. ${ }^{24,26,52}$ The benefit of CRT in patients with atrial fibrillation is more pronounced in those with depressed ejection fraction. ${ }^{25}$ Similarly, patients receiving prophylactic ICDs often evolve progressively to dominant ventricular pacing, which may reflect both intrinsic chronotropic incompetence and aggressive up-titration of beta-adrenergic-blocking agents.

When device implantation or reimplantation is being considered for patients who require ventricular pacing, it is prudent to recall the results of the DAVID (Dual Chamber and VVI Implantable Defibrillator) trial. ${ }^{53}$ In this trial, dualchamber rate-responsive pacing increased HF admissions and mortality rate as compared to sinus rhythm. A cutoff of approximately $40 \%$ right ventricular pacing was seen as deleterious. ${ }^{54}$ Similarly, in a substudy from MADIT-II (Multicenter Automatic Defibrillator Implantation Trial II), patients who were right ventricular paced $>50 \%$ of the time had a higher rate of new or worsened HF than those right ventricular paced $\leq 50 \%$ of the time. ${ }^{55}$

The major experience with resynchronization derives from patients with NYHA class III symptoms of HF and LVEF $\leq 35 \%$. Patients with NYHA class IV symptoms of HF have accounted for only $10 \%$ of all patients in clinical trials of resynchronization therapy. These patients were highly selected ambulatory outpatients who were taking oral medications and had no history of recent hospitalization. ${ }^{56}$ Although a benefit has occasionally been described in patients with more severe acute decompensation that required brief positive intravenous inotropic therapy to aid diuresis, CRT is not generally used as a "rescue therapy" for such patients. Patients with dependence on intravenous inotropic therapy, refractory fluid retention, or advanced chronic kidney disease represent the highest-risk population for complications of any procedure and for early death after hospital discharge, and they are also unlikely to receive 
a meaningful mortality risk benefit from concomitant defibrillator therapy. ${ }^{19,57}$

Patients with NYHA class IV HF symptoms who derive functional benefit from resynchronization therapy may return to a better functional status, in which prevention of sudden death becomes a relevant goal. Even among the selected NYHA class IV patients identified within the COMPANION trial, ${ }^{17}$ there was no difference in 2-year survival rate between the CRT patients with and without backup defibrillation, although more of the deaths in the CRT-Pacemaker group were classified as sudden deaths. ${ }^{56}$

Perhaps the most significant changes in the present document compared to the 2008 DBT Guideline ${ }^{4}$ are the expansion of the Class I recommendation for CRT to include patients with LBBB, QRS duration $\geq 150 \mathrm{~ms}$, and NYHA class II and the addition of a Class IIb recommendation for patients who have LVEF $\leq 30 \%$, ischemic etiology of HF, sinus rhythm, LBBB with a QRS duration of $\geq 150$ $\mathrm{ms}$, and NYHA class I symptoms. These recommendations are based on 4 studies in which CRT was evaluated in patients with minimal or mild symptoms of HF in the setting of low LVEF. These include MADIT-CRT, RAFT, REVERSE (Resynchronization Reverses Remodeling in Systolic Left Ventricular Dysfunction), and MIRACLE ICD II (Multicenter InSync ICD Randomized Clinical Evaluation II), all of which are discussed in the following paragraphs. ${ }^{20-22,58}$

MADIT-CRT ${ }^{20}$ randomized patients with NYHA class I or II ischemic and NYHA class II nonischemic cardiomyopathy, LVEF $\leq 30 \%$, and QRS duration $\geq 130 \mathrm{~ms}$ on GDMT to CRT-D or ICD alone. Of note, only $15 \%$ of the total cohort of patients were NYHA class I. The primary endpoint, a composite of death or HF event, was reduced by $34 \%$ by CRT-D (HR, 0.66), with comparable benefit for both ischemic and nonischemic etiology of HF. HF events were reduced by $41 \%$, without significant reduction in mortality rate. CRT-D therapy was demonstrated to be of more benefit in women than in men (HR: 0.37 and 0.76 , respectively) and in patients with QRS duration $\geq 150 \mathrm{~ms}$ than in patients with $\mathrm{QRS}$ duration $<150$ ms (HR: 0.48 and 1.06, respectively). ${ }^{20}$ Patients with LBBB had a significant reduction in ventricular tachycardia, ventricular fibrillation, and death compared to nonLBBB patients, who derived no benefit (HR: 0.47 and 1.24 , respectively). ${ }^{10}$

RAFT $^{21}$ reported the use of CRT-D in patients with NYHA class II or class III ischemic or nonischemic cardiomyopathy, LVEF $\leq 30 \%$, and QRS duration $\geq 120 \mathrm{~ms}$, as compared to those treated with an ICD alone. The primary outcome of death or hospitalization for HF occurred in 33\% of patients receiving CRT-D and in $40 \%$ of patients receiving ICD only. RAFT not only showed a significant reduction in hospitalization for HF (HR, 0.68; 95\% CI, 0.56 to 0.83 ; $P<.001)$ but also was the first study to show a statistically significant reduction in death (HR, $0.75 ; 95 \% \mathrm{CI}, 0.62$ to $0.91 ; P=.003)$ in mildly symptomatic patients with NYHA class II symptoms. However, CRT-D was associated with a higher risk of adverse device- or implantation-related complications at 30 days after implantation $(P<.001)$ compared with an ICD and no CRT. Patients with LBBB had a better outcome than did non-LBBB patients, but the statistical interaction between benefit and QRS morphology was weak in this trial $(P=.046)$. CRT-D therapy was effective in patients with QRS duration $\geq 150 \mathrm{~ms}$ but of no benefit in patients with QRS duration $<150 \mathrm{~ms}$ (HR for QRS duration $\geq 150 \mathrm{~ms}, 0.59 ; 95 \% \mathrm{CI}, 0.48$ to 0.73 ; HR for QRS duration <150 ms, 0.99 ; $95 \%$ CI, 0.77 to 1.27 ; $P=.002$ for interaction). Thus, both MADIT-CRT and RAFT showed benefit in NYHA class II patients treated with CRT-D and demonstrated that the benefit was primarily achieved in patients with QRS duration $\geq 150 \mathrm{~ms}$ and LBBB. $^{20,21}$

The REVERSE trial consisted of 610 patients. This study assessed CRT-D therapy in patients with NYHA class I or II HF symptoms on maximum medical therapy, LVEF $\leq 40 \%$, and QRS duration $\geq 120$ ms followed for 12 months and showed that $16 \%$ of patients receiving CRT and $21 \%$ without CRT worsened $(P=.10)$. The time to first HF hospitalization was delayed in patients receiving CRT therapy (HR, 0.47). The primary echocardiographic endpoint of ventricular remodeling assessed by LV end-systolic volume index was significantly improved (reduction in end-systolic volume index) in patients treated with CRT therapy $(P<.0001)$. REVERSE did not report a mortality rate benefit of CRT-D therapy. ${ }^{22}$ The lack of reported mortality rate benefit may be related to the higher ejection fraction enrollment criterion (LVEF $\leq 40 \%)$ and the relatively short-term follow-up (12 months). ${ }^{22}$

MIRACLE ICD II included patients with NYHA class II HF on GDMT with LVEF $\leq 35 \%$ and QRS duration $\geq 130$ $\mathrm{ms}$ who were undergoing implantation of an otherwise indicated ICD. ${ }^{58}$ In these patients, CRT did not alter exercise capacity but did result in significant improvement in cardiac structure and function and composite clinical response over 6 months.

Analysis of the multiple clinical trials of CRT is complicated because trials encompass a range of LVEFs in their entry criteria, as well as a range of measured outcomes. For mortality rate, the trials showing benefit in NYHA class III and IV patients typically included those with LVEF $\leq 35 \% .^{22,58}$ For patients with NYHA class II, trials showing mortality rate benefit included those with LVEF $\leq 30 \%{ }^{20,21}$ A mortality rate benefit with CRT has not been shown for patients who are NYHA class I. ${ }^{21}$ In terms of demonstrating improvement in cardiac function (eg, significant reduction in LV size and improvement in ejection fraction), trials have included patients with LVEF $\leq 35 \%$ 
who are NYHA class III and IV. ${ }^{58}$ Similarly, for patients with LVEF $\leq 40 \%$, trials demonstrating improvement in function have included those who are NYHA class I and II. $^{22}$ The congruence of results from the totality of CRT trials with regard to remodeling and HF events provides evidence supporting a common threshold of $35 \%$ for benefit from CRT in patients with NYHA class II through IV HF symptoms. Although there is evidence for benefit in both CRT-D and CRT-Pacemaker patients with NYHA class III and IV symptoms, for NYHA class I and II HF, all of the trials tested only CRT-D and not CRT-Pacemaker, and as such, recommendations for these classes of patients can be made only for CRT-D. ${ }^{20-22,58}$

Taken together, the evidence from the randomized trials of CRT-D in patients with reduced LVEF and NYHA class I or II shows that CRT can provide functional improvement and decrease the risk of HF events and composite outcomes. $^{20,22,58,59}$ Still, CRT-D also has been shown to decrease the mortality rate for patients with NYHA class II but not for those who have NYHA class I HF. ${ }^{20,21}$ As a result, the data support a Class I recommendation for CRT implantation in patients with LBBB and QRS duration $\geq 150 \mathrm{~ms}$ and NYHA class II. Because of the lack of mortality rate benefit and smaller sample size, we believe CRT may be considered for patients who have LVEF $<30 \%$, ischemic etiology of HF, sinus rhythm, LBBB with a QRS duration $\geq 150 \mathrm{~ms}$, and NYHA class I symptoms on GDMT (Class IIb; LOE: B).

For all patients, optimal outcomes with CRT require effective placement of ventricular leads, ongoing HF management with neurohormonal antagonists and diuretic therapy, and in some cases, later optimization of device programming, especially atrioventricular $(\mathrm{A}-\mathrm{V})$ and interventricular (V-V) intervals. ${ }^{51-60}$

Consistent with entry criteria for studies upon which these recommendations are based, CRT implantation should be performed only when the LVEF meets guideline criteria for patients with nonischemic cardiomyopathy who have received $>3$ months of GDMT, or for patients with ischemic cardiomyopathy $>40$ days after myocardial infarction receiving GDMT when there was no intervening revascularization, or $>3$ months if revascularization was performed. It is assumed that the final decision to recommend CRT will be based on an assessment of LVEF made after any appropriate waiting period has concluded, during which GDMT has been applied. Finally, the pivotal trials demonstrating the efficacy of CRT took place in centers that provided expertise in device and HF therapy both at implantation and during long-term follow-up.

Two other organizational guidelines by the Heart Failure Society of America ${ }^{61}$ and the European Society of Cardiology ${ }^{62}$ have recently been published that address indications for CRT. For the patient categories in common between the Heart Failure Society of America document and the present focused update, there was a good deal of concordance. Although there are many areas of agreement, some differences exist between the present guideline and the European Society of Cardiology document. One difference is that in the present guideline, CRT is recommended in NYHA class I patients who have LVEF $\leq 30 \%$, have ischemic heart disease, are in sinus rhythm, and have a LBBB with a QRS duration $\geq 150 \mathrm{~ms}$ (Class IIb; LOE: C) ${ }^{20,21}$ There is no similar recommendation in the European Society of Cardiology document. The European Society of Cardiology recommendations include patients with QRS duration $<120 \mathrm{~ms}$. We have not recommended CRT for any functional class or ejection fraction with QRS durations $<120 \mathrm{~ms}$. We also have elected to consider the presence of LBBB versus non-LBBB in the class of recommendations, on the basis of perceived differential benefit by functional class, QRS morphology, and QRS duration.

\subsection{Pacemaker Follow-up}

\subsubsection{Remote Follow-up and Monitoring}

Since the publication of the 2008 DBT guideline, important changes have occurred related to follow-up and remote monitoring of CIEDs. ${ }^{4,15,63}$ CIEDs include pacemakers, ICDs, CRTs, implantable loop recorders, and implantable cardiovascular monitors. The current technology for follow-up, evidence supporting its use, and clinical practice of CIED monitoring have evolved. Routine in-person office follow-up supplemented by transtelephonic monitoring with limited remote follow-up for pacemakers was the standard approach before 2008., ${ }^{45}$ Transtelephonic monitoring, with monitors that transmit the patient's heart rhythm by converting electrocardiographic information to sound and transmitting it via telephone lines to a decoding machine that then converts the sound back into a rhythm strip, is now a dated technique ${ }^{4,15,63}$ because it allows for limited monitoring of heart rate, rhythm, and battery status of only pacemakers. ${ }^{63}$

Contemporary remote monitoring uses bidirectional telemetry with encoded and encrypted radiofrequency signals, allowing transmission and receipt of information from CIEDs (pacemakers, ICDs, CRTs, implantable loop recorders, and implantable hemodynamic monitors). ${ }^{63}$ All major CIED manufacturers have developed proprietary systems to allow patients to have their devices interrogated remotely, and many use wireless cellular technology to extend the bidirectional telemetry links into the patient's location. ${ }^{15,63}$ The information is analyzed, formatted, and transmitted to a central server, where it can be accessed by clinicians through the Internet. Information provided through remote follow-up includes virtually all of the stored information that would be obtained in an in-office visit, including battery voltage, charge time in ICDs, 
TABLE 3. Minimum frequency of CIED in-person or remote monitoring*

\begin{tabular}{|c|c|}
\hline Type and frequency & Method \\
\hline \multicolumn{2}{|l|}{ Pacemaker/ICD/CRT } \\
\hline Within $72 \mathrm{~h}$ of CIED implantation & In person \\
\hline 2-12 wk postimplantation & In person \\
\hline Every 3-12 mo for pacemaker/CRT-Pacemaker & In person or remote \\
\hline Every 3-6 mo for ICD/CRT-D & In person or remote \\
\hline Annually until battery depletion & In person \\
\hline Every 1-3 mo at signs of battery depletion & In person or remote \\
\hline \multicolumn{2}{|l|}{ Implantable loop recorder } \\
\hline $\begin{array}{l}\text { Every 1-6 mo depending on patient symptoms } \\
\text { and indication }\end{array}$ & In person or remote \\
\hline \multicolumn{2}{|l|}{ Implantable hemodynamic monitor } \\
\hline Every 1-6 mo depending on indication & In person or remote \\
\hline More frequent assessment as clinically indicated & In person or remote \\
\hline
\end{tabular}

percent pacing, sensing thresholds, automatically measured pacing thresholds when available, pacing and shock impedance, and stored arrhythmia events with electrograms. ${ }^{15,63}$ CIEDs with wireless telemetry capability may be programmed at a face-to-face evaluation to subsequently send automatic alerts for a variety of issues that the clinician deems significant, such as abnormal battery voltage, abnormal lead parameters, or increased duration or frequency of arrhythmia episodes. ${ }^{15}$ Remote transmissions can be made at predetermined intervals or at unscheduled times for prespecified alerts related to device function or activated by the patient for clinical reasons. ${ }^{63}$ A detailed description of techniques, indications, personnel, and frequency has been published as a consensus document. ${ }^{15}$

Several prospective randomized trials have been conducted evaluating the effect of remote monitoring on clinical outcomes ${ }^{64-67}$ since the publication of the 2008 DBT Guideline. ${ }^{4}$ Collectively, these trials have demonstrated that remote monitoring is a safe alternative to office visits to evaluate CIEDs. Compared with in-person office visits to evaluate CIEDs, remote monitoring leads to early discovery of clinically actionable events, decreased time to clinical decision in response to these events, and fewer office visits. ${ }^{64-67}$ Long-term survival rates of patients monitored remotely with ICDs in a practice setting compare favorably with survival rates of patients in clinical trials. ${ }^{68}$

Current suggestions for the minimum frequency of inoffice and remote monitoring of patients with CIEDs are summarized in Table $3 .{ }^{15}$ Issues such as lead malfunction, unreliable battery life indicators, and other device or lead recalls influence clinical decisions, which may change the appropriate minimum follow-up.

\section{PRESIDENTS AND STAFF}

\section{American College of Cardiology Foundation}

William A. Zoghbi, MD, FACC, President

Thomas E. Arend, Jr, Esq, CAE, Interim Chief Staff Officer

Charlene May, Senior Director, Science and Clinical Policy

American College of Cardiology Foundation/American Heart Association

Lisa Bradfield, CAE, Director, Science and Clinical Policy

Debjani Mukherjee, MPH, Associate Director, Evidence-

Based Medicine

Ezaldeen Ramadhan III, Specialist, Science and Clinical Policy

\section{American Heart Association}

Gordon F. Tomaselli, MD, FAHA, President

Nancy Brown, Chief Executive Officer

Rose Marie Robertson, MD, FAHA, Chief Science Officer

Gayle R. Whitman, PhD, RN, FAHA, FAAN, Senior Vice President, Office of Science Operations

Judy L. Bezanson, DSN, RN, CNS-MS, FAHA, Science and Medicine Advisor, Office of Science Operations

Jody Hundley, Production Manager, Scientific Publications, Office of Science Operations

\section{References}

1. ACCF/AHATask Force on Practice Guidelines. Methodology Manual and Policies From the ACCF/AHA Task Force on Practice Guidelines. American College of Cardiology Foundation and American Heart Association, Inc. 2010, http:// assets.cardiosource.com/Methodology_Manual_for_ACC_AHA_Writing_ Committees.pdf and http://my.americanheart.org/idc/groups/ahamah-public/@ wcm/@sop/documents/downloadable/ucm_319826.pdf. Accessed May 16, 2012.

2. Committee on Standards for Systematic Reviews of Comparative Effectiveness Research, Institute of Medicine. Finding What Works in Health Care: Standards for Systematic Reviews. Washington, DC: The National Academies Press; 2011.

3. Committee on Standards for Developing Trustworthy Clinical Practice Guidelines, Institute of Medicine. Clinical Practice Guidelines We Can Trust. Washington, DC: The National Academies Press; 2011.

4. Epstein AE, DiMarco JP, Ellenbogen KA, et al. ACC/AHA/HRS 2008 guidelines for device-based therapy of cardiac rhythm abnormalities: a report of the American College of Cardiology/American Heart Association Task Force on Practice Guidelines (Writing Committee to Revise the ACC/AHA/NASPE 2002 Guideline Update for Implantation of Cardiac Pacemakers and Antiarrhythmia Devices). J Am Coll Cardiol. 2008;51:e1-62.

5. Gersh BJ, Maron BJ, Bonow RO, et al. 2011 ACCF/AHA guideline for the diagnosis and treatment of hypertrophic cardiomyopathy: a report of the American College of Cardiology Foundation/American Heart Association Task Force on Practice Guidelines. J Am Coll Cardiol. 2011;58:e212-60.

6. Ackerman MJ, Priori SG, Willems S, et al. HRS/EHRA expert consensus statement on the state of genetic testing for the channelopathies and cardiomyopathies. Heart Rhythm. 2011;8:1308-39.

7. Horner JM, Kinoshita M, Webster TL, et al. Implantable cardioverter defibrillator therapy for congenital long QT syndrome: a single-center experience. Heart Rhythm. 2010;7:1616-22

8. Schwartz PJ, Spazzolini C, Priori SG, et al. Who are the long-QT syndrome patients who receive an implantable cardioverter-defibrillator and what happens to them? Data from the European Long-QT Syndrome Implantable CardioverterDefibrillator (LQTS ICD) Registry. Circulation. 2010;122:1272-82. 
9. Berul CI, Van Hare GF, Kertesz NJ, et al. Results of a multicenter retrospective implantable cardioverter-defibrillator registry of pediatric and congenital heart disease patients. J Am Coll Cardiol. 2008;51:1685-91.

10. Barsheshet A, Wang PJ, Moss AJ, et al. Reverse remodeling and the risk of ventricular tachyarrhythmias in the MADIT-CRT (Multicenter Automatic Defibrillator Implantation Trial-Cardiac Resynchronization Therapy). J Am Coll Cardiol. 2011;57:2416-23.

11. Silka MJ, Bar-Cohen Y. Should patients with congenital heart disease and a systemic ventricular ejection fraction less than $30 \%$ undergo prophylactic implantation of an ICD? Patients with congenital heart disease and a systemic ventricular ejection fraction less than $30 \%$ should undergo prophylactic implantation of an implantable cardioverter defibrillator. Circ Arrhythm Electrophysiol. 2008;1:298-306.

12. Khairy P, Harris L, Landzberg MJ, et al. Implantable cardioverter-defibrillators in tetralogy of Fallot. Circulation. 2008;117:363-70.

13. van der Hulst AE, Delgado V, Blom NA, et al. Cardiac resynchronization therapy in paediatric and congenital heart disease patients. Eur Heart J. 2011;32: 2236-46.

14. Lampert R, Hayes DL, Annas GJ, et al. HRS expert consensus statement on the management of cardiovascular implantable electronic devices (CIEDs) in patients nearing end of life or requesting withdrawal of therapy. Heart Rhythm. 2010;7:1008-26.

15. Wilkoff BL, Auricchio A, Brugada J, et al. HRS/EHRA expert consensus on the monitoring of cardiovascular implantable electronic devices (CIEDs): description of techniques, indications, personnel, frequency and ethical considerations. Heart Rhythm. 2008;5:907-25.

16. Abraham WT, Fisher WG, Smith AL, et al. Cardiac resynchronization in chronic heart failure. N Engl J Med. 2002;346:1845-53.

17. Bristow MR, Saxon LA, Boehmer J, et al. Cardiac-resynchronization therapy with or without an implantable defibrillator in advanced chronic heart failure. N Engl J Med. 2004;350:2140-50.

18. Cleland JGF, Daubert J-C, Erdmann E, et al. The effect of cardiac resynchronization on morbidity and mortality in heart failure. $N$ Engl J Med. 2005;352: 1539-49.

19. Hunt SA, Abraham WT, Chin MH, et al. 2009 Focused update incorporated into the ACC/AHA 2005 guidelines for the diagnosis and management of heart failure in adults: a report of the American College of Cardiology Foundation/American Heart Association Task Force on Practice Guidelines. Circulation. 2009;119: e391-479.

20. Moss AJ, Hall WJ, Cannom DS, et al. Cardiac-resynchronization therapy for the prevention of heart-failure events. N Engl J Med. 2009;361:1329-38.

21. Tang ASL, Wells GA, Talajic M, et al. Cardiac-resynchronization therapy for mild-to-moderate heart failure. $N$ Engl J Med. 2010;363:2385-95.

22. Linde C, Abraham WT, Gold MR, et al. Randomized trial of cardiac resynchronization in mildly symptomatic heart failure patients and in asymptomatic patients with left ventricular dysfunction and previous heart failure symptoms. $J$ Am Coll Cardiol. 2008;52:1834-43.

23. Brignole M, Gammage M, Puggioni E, et al. Comparative assessment of right, left, and biventricular pacing in patients with permanent atrial fibrillation. Eur Heart J. 2005;26:712-22.

24. Brignole M, Botto G, Mont L, et al. Cardiac resynchronization therapy in patients undergoing atrioventricular junction ablation for permanent atrial fibrillation: a randomized trial. Eur Heart J. 2011;32:2420-9.

25. Doshi RN, Daoud EG, Fellows C, et al. Left ventricular-based cardiac stimulation post AV nodal ablation evaluation (the PAVE study). J Cardiovasc Electrophysiol. 2005;16:1160-5.

26. Gasparini M, Auricchio A, Regoli F, et al. Four-year efficacy of cardiac resynchronization therapy on exercise tolerance and disease progression: the importance of performing atrioventricular junction ablation in patients with atrial fibrillation. J Am Coll Cardiol. 2006;48:734-43.

26a. Wilton SB, Leung AA, Ghali WA, et al. Outcomes of cardiac resynchronization therapy in patients with versus those without atrial fibrillation: a systematic review and meta-analysis. Heart Rhythm. 2011;8:1088-94.

27. Wilkoff BL, Cook JR, Epstein AE, et al. Dual-chamber pacing or ventricular backup pacing in patients with an implantable defibrillator: the Dual Chamber and VVI Implantable Defibrillator (DAVID) Trial. JAMA. 2002;288: 3115-23.

28. Adelstein E, Schwartzman D, Gorcsan J 3rd, Saba S. Predicting hyperresponse among pacemaker-dependent nonischemic cardiomyopathy patients upgraded to cardiac resynchronization. J Cardiovasc Electrophysiol. 2011;22: 905-11.
29. Vatankulu MA, Goktekin O, Kaya MG, et al. Effect of long-term resynchronization therapy on left ventricular remodeling in pacemaker patients upgraded to biventricular devices. Am J Cardiol. 2009;103:1280-4.

30. Rickard J, Bassiouny M, Cronin EM, et al. Predictors of response to cardiac resynchronization therapy in patients with a non-left bundle branch block morphology. Am J Cardiol. 2011;108:1576-80.

31. Masci PG, Marinelli M, Piacenti M, et al. Myocardial structural, perfusion, and metabolic correlates of left bundle branch block mechanical derangement in patients with dilated cardiomyopathy: a tagged cardiac magnetic resonance and positron emission tomography study. Circ Cardiovasc Imaging. 2010;3:482-90.

32. Kashani A, Barold SS. Significance of QRS complex duration in patients with heart failure. J Am Coll Cardiol. 2005;46:2183-92.

33. Doval HC, Nul DR, Grancelli HO, et al. Randomised trial of low-dose amiodarone in severe congestive heart failure: Grupo de Estudio de la Sobrevida en la Insuficiencia Cardiaca en Argentina (GESICA). Lancet. 1994;344:493-8.

34. Bleeker GB, Schalij MJ, Molhoek SG, et al. Relationship between QRS duration and left ventricular dyssynchrony in patients with end-stage heart failure. J Cardiovasc Electrophysiol. 2004;15:544-9.

35. Blanc JJ, Etienne Y, Gilard M, et al. Evaluation of different ventricular pacing sites in patients with severe heart failure: results of an acute hemodynamic study. Circulation. 1997;96:3273-7.

36. Prinzen FW, Vernooy K, De Boeck BWL, et al. Mechano-energetics of the asynchronous and resynchronized heart. Heart Fail Rev. 2011;16:215-24.

37. Ukkonen H, Sundell J, Knuuti J. Effects of CRT on myocardial innervation, perfusion and metabolism. Europace. 2008;10(Suppl 3):iii114-7.

38. Cazeau S, Leclercq C, Lavergne T, et al. Effects of multisite biventricular pacing in patients with heart failure and intraventricular conduction delay. $N$ Engl J Med. 2001;344:873-80.

39. Stellbrink C, Breithardt OA, Franke A, et al. Impact of cardiac resynchronization therapy using hemodynamically optimized pacing on left ventricular remodeling in patients with congestive heart failure and ventricular conduction disturbances. J Am Coll Cardiol. 2001;38:1957-65.

40. Bradley DJ, Bradley EA, Baughman KL, et al. Cardiac resynchronization and death from progressive heart failure: a meta-analysis of randomized controlled trials. JAMA. 2003;289:730-40.

41. Haghjoo M, Bagherzadeh A, Fazelifar AF, et al. Prevalence of mechanical dyssynchrony in heart failure patients with different QRS durations. Pacing Clin Electrophysiol. 2007;30:616-22.

42. Stavrakis S, Lazzara R, Thadani U. The benefit of cardiac resynchronization therapy and QRS duration: a meta-analysis. J Cardiovasc Electrophysiol. 2012;23: $163-8$.

43. Sipahi I, Carrigan TP, Rowland DY, et al. Impact of QRS duration on clinical event reduction with cardiac resynchronization therapy: meta-analysis of randomized controlled trials. Arch Intern Med. 2011;171:1454-62.

44. Saxon LA, Ellenbogen KA. Resynchronization therapy for the treatment of heart failure. Circulation. 2003;108:1044-8.

45. Bilchick KC, Kamath S, DiMarco JP, Stukenborg GJ. Bundle-branch block morphology and other predictors of outcome after cardiac resynchronization therapy in Medicare patients. Circulation. 2010;122:2022-30.

46. Adelstein EC, Saba S. Usefulness of baseline electrocardiographic QRS complex pattern to predict response to cardiac resynchronization. Am J Cardiol. 2009;103: $238-42$.

47. Rickard J, Kumbhani DJ, Gorodeski EZ, et al. Cardiac resynchronization therapy in non-left bundle branch block morphologies. Pacing Clin Electrophysiol. 2010; 33:590-5.

48. Upadhyay GA, Choudhry NK, Auricchio A, et al. Cardiac resynchronization in patients with atrial fibrillation: a meta-analysis of prospective cohort studies. $J$ Am Coll Cardiol. 2008;52:1239-46.

49. Beshai JF, Grimm RA, Nagueh SF, et al. Cardiac-resynchronization therapy in heart failure with narrow QRS complexes. $N$ Engl J Med. 2007;357: 2461-71.

50. Ariga R, Tayebjee MH, Benfield A, et al. Greater three-dimensional ventricular lead tip separation is associated with improved outcome after cardiac resynchronization therapy. Pacing Clin Electrophysiol. 2010;33:1490-6.

51. Singh JP, Klein HU, Huang DT, et al. Left ventricular lead position and clinical outcome in the multicenter automatic defibrillator implantation trialcardiac resynchronization therapy (MADIT-CRT) trial. Circulation. 2011;123: 1159-66.

52. Linde C, Leclercq C, Rex S, et al. Long-term benefits of biventricular pacing in congestive heart failure: results from the MUltisite STimulation in cardiomyopathy (MUSTIC) study. J Am Coll Cardiol. 2002;40:111-8. 
53. Sweeney MO, Prinzen FW. A new paradigm for physiologic ventricular pacing. $J$ Am Coll Cardiol. 2006;47:282-8.

54. Sharma AD, Rizo-Patron C, Hallstrom AP, et al. Percent right ventricular pacing predicts outcomes in the DAVID trial. Heart Rhythm. 2005;2:830-4.

55. Steinberg JS, Fischer A, Wang P, et al. The clinical implications of cumulative right ventricular pacing in the Multicenter Automatic Defibrillator Trial II. J Cardiovasc Electrophysiol. 2005;16:359-65.

56. Lindenfeld J, Feldman AM, Saxon L, et al. Effects of cardiac resynchronization therapy with or without a defibrillator on survival and hospitalizations in patients with New York Heart Association class IV heart failure. Circulation. 2007;115: 204-12.

57. Amin MS, Fox AD, Kalahasty G, et al. Benefit of primary prevention implantable cardioverter-defibrillators in the setting of chronic kidney disease: a decision model analysis. J Cardiovasc Electrophysiol. 2008;19:1275-80.

58. Abraham WT, Young JB, León AR, et al. Effects of cardiac resynchronization on disease progression in patients with left ventricular systolic dysfunction, an indication for an implantable cardioverter-defibrillator, and mildly symptomatic chronic heart failure. Circulation. 2004;110:2864-8.

59. Daubert C, Gold MR, Abraham WT, et al. Prevention of disease progression by cardiac resynchronization therapy in patients with asymptomatic or mildly symptomatic left ventricular dysfunction: insights from the European cohort of the REVERSE (Resynchronization Reverses Remodeling in Systolic Left Ventricular Dysfunction) trial. J Am Coll Cardiol. 2009;54: 1837-46.

60. Singh JP, Gras D. Biventricular pacing: current trends and future strategies. Eur Heart J. 2012;33:305-13.
61. Stevenson WG, Hernandez AF, Carson PE, et al. Indications for cardiac resynchronization therapy: 2011 update from the Heart Failure Society of America Guideline Committee. J Card Fail. 2012;18:94-106.

62. Dickstein K, Vardas PE, Auricchio A, et al. 2010 Focused update of ESC guidelines on device therapy in heart failure: an update of the 2008 ESC guidelines for the diagnosis and treatment of acute and chronic heart failure and the 2007 ESC guidelines for cardiac and resynchronization therapy. Eur Heart J. 2010;31:2677-87.

63. Dubner S, Auricchio A, Steinberg JS, et al. ISHNE/EHRA expert consensus on remote monitoring of cardiovascular implantable electronic devices (CIEDs). Europace. 2012;14:278-93.

64. Crossley GH, Chen J, Choucair W, et al. Clinical benefits of remote versus transtelephonic monitoring of implanted pacemakers. J Am Coll Cardiol. 2009;54: 2012-9.

65. Crossley GH, Boyle A, Vitense H, et al. The CONNECT (Clinical Evaluation of Remote Notification to Reduce Time to Clinical Decision) trial: the value of wireless remote monitoring with automatic clinician alerts. J Am Coll Cardiol. 2011; 57:1181-9.

66. Varma N, Epstein AE, Irimpen A, et al. Efficacy and safety of automatic remote monitoring for implantable cardioverter-defibrillator follow-up: the Lumos-T Safely Reduces Routine Office Device Follow-up (TRUST) trial. Circulation. 2010;122:325-32.

67. Mabo P, Victor F, Bazin P, et al. A randomized trial of long-term remote monitoring of pacemaker recipients (the COMPAS trial). Eur Heart J. 2012;33:1105-11.

68. Saxon LA, Hayes DL, Gilliam FR, et al. Long-term outcome after ICD and CRT implantation and influence of remote device follow-up: the ALTITUDE surviva study. Circulation. 2010;122:2359-67. 
APPENDIX 1. Author relationships with industry and other entities (relevant)—2012 ACCF/AHA/HRS focused update of the 2008 guidelines for device-based therapy of cardiac rhythm abnormalities

\begin{tabular}{|c|c|c|c|c|c|c|c|c|}
\hline $\begin{array}{c}\text { Committee } \\
\text { member }\end{array}$ & Employment & Consultant & $\begin{array}{c}\text { Speaker's } \\
\text { bureau }\end{array}$ & $\begin{array}{l}\text { Ownership/ } \\
\text { partnership/ } \\
\text { principal }\end{array}$ & $\begin{array}{l}\text { Personal } \\
\text { research }\end{array}$ & $\begin{array}{c}\begin{array}{c}\text { Institutional, } \\
\text { organizational, } \\
\text { or other financial } \\
\text { benefit }\end{array} \\
\end{array}$ & $\begin{array}{l}\text { Expert } \\
\text { witness }\end{array}$ & $\begin{array}{c}\text { Voting } \\
\text { recusals } \\
\text { by section* }\end{array}$ \\
\hline $\begin{array}{l}\text { Cynthia M. Tracy, } \\
\text { Chair }\end{array}$ & $\begin{array}{l}\text { George Washington } \\
\text { University Medical } \\
\text { Center-Associate } \\
\text { Director and Professor } \\
\text { of Medicine }\end{array}$ & None & None & None & None & None & None & None \\
\hline $\begin{array}{l}\text { Andrew E. Epstein, } \\
\text { Vice Chair }\end{array}$ & $\begin{array}{l}\text { University of } \\
\text { Pennsylvania } \\
\text { —Professor of } \\
\text { MedicinePhiladelphia } \\
\text { VA Medical Center- } \\
\text { Chief, Cardiology } \\
\text { Section }\end{array}$ & $\begin{aligned} \text { - } & \text { Boston Scientific } \\
& \text { (DSMB) } \dagger \\
\text { - } & \text { Medtronic } \ddagger \\
\text { - } & \text { Medtronic/CryoCath } \\
& \text { (DSMB) } \\
\text { - } & \text { St. Jude Medical } \\
& \text { (DSMB) } \dagger \\
\text { - } & \text { ZOLL-Advisory } \\
& \text { Board }\end{aligned}$ & None & None & $\begin{array}{l}\text { - } \text { Biotronik } \\
\text { - } \text { Boston } \\
\text { Scientific } \dagger \\
\text { - } \text { Cameron } \\
\text { Health } \dagger \\
\text { - } \text { Medtronic } \dagger \\
\text { - St. Jude } \\
\text { Medical } \dagger\end{array}$ & $\begin{array}{l}\text { - Boston Scientific } \\
\text { - Medtronic } \\
\text { - St. Jude Medical }\end{array}$ & None & 2.4 .1 \\
\hline Dawood Darbar & $\begin{array}{l}\text { Vanderbilt University } \\
\text { School of Medicine_- } \\
\text { C. Sydney Burwell } \\
\text { Associate Professor } \\
\text { Medicine } \\
\text { Pharmacology } \\
\text { Vanderbilt } \\
\text { Arrhythmia } \\
\text { Service-Director }\end{array}$ & None & None & None & None & None & None & None \\
\hline John P. DiMarco & $\begin{array}{l}\text { University of Virginia- } \\
\text { Director, Clinical EP } \\
\text { Laboratory }\end{array}$ & $\begin{array}{l}\text { - Medtronic } \\
\text { - St. Jude Medical }\end{array}$ & None & None & $\begin{array}{l}\text { - Boston } \\
\text { Scientific }\end{array}$ & None & None & 2.4 .1 \\
\hline Sandra B. Dunbar & $\begin{array}{l}\text { Emory University, Nell } \\
\text { Hodgson Woodruff } \\
\text { School of Nursing- } \\
\text { Associate Dean for } \\
\text { Academic } \\
\text { Advancement, } \\
\text { Charles } \\
\text { Howard Candler } \\
\text { Professor }\end{array}$ & None & None & None & None & None & None & None \\
\hline N.A. Mark Estes III & $\begin{array}{l}\text { Tufts University- } \\
\text { Professor of Medicine }\end{array}$ & $\begin{array}{l}\text { - Boston Scientific } \dagger \\
\text { - Boston Scientific, EP } \\
\text { Fellowship } \\
\text { Educational } \\
\text { Symposium } \dagger \\
\text { - } \text { Medtronic }\end{array}$ & None & None & $\begin{array}{l}\text { - } \text { Boston } \\
\text { Scientific- } \\
\text { MADIT-RIT } \\
\text { (Co-PI) }\end{array}$ & None & None & 2.4 .1 \\
\hline $\begin{array}{l}\text { T. Bruce } \\
\text { Ferguson, Jr }\end{array}$ & $\begin{array}{l}\text { East Carolina } \\
\text { University- } \\
\text { Professor of Surgery } \\
\text { and Physiology }\end{array}$ & $\begin{array}{l}\text { - United Healthcare- } \\
\text { Advisory Board }\end{array}$ & None & None & None & None & None & 2.4 .1 \\
\hline Stephen C. Hammill & $\begin{array}{l}\text { Mayo Clinic_Professor } \\
\text { of Medicine }\end{array}$ & None & None & None & None & None & None & None \\
\hline Pamela E. Karasik & $\begin{array}{l}\text { Georgetown University } \\
\text { Medical School- } \\
\text { Associate Professor of } \\
\text { Medicine } \\
\text { VA Medical } \\
\text { Center, Washington, } \\
\text { DC-Acting Chief of } \\
\text { Cardiology }\end{array}$ & None & None & None & None & None & None & None \\
\hline
\end{tabular}


APPENDIX 1. Continued

\begin{tabular}{|c|c|c|c|c|c|c|c|c|}
\hline $\begin{array}{l}\text { Committee } \\
\text { member }\end{array}$ & Employment & Consultant & $\begin{array}{c}\text { Speaker's } \\
\text { bureau }\end{array}$ & $\begin{array}{c}\text { Ownership/ } \\
\text { partnership/ } \\
\text { principal }\end{array}$ & $\begin{array}{l}\text { Personal } \\
\text { research }\end{array}$ & $\begin{array}{c}\text { Institutional, } \\
\text { organizational, } \\
\text { or other financial } \\
\text { benefit }\end{array}$ & $\begin{array}{l}\text { Expert } \\
\text { witness }\end{array}$ & $\begin{array}{c}\text { Voting } \\
\text { recusals } \\
\text { by section* }\end{array}$ \\
\hline Mark S. Link & $\begin{array}{l}\text { Tufts Medical Center- } \\
\text { Professor of Medicine }\end{array}$ & None & None & None & $\begin{array}{l}\text { - } \text { Boston } \\
\text { Scientific- } \\
\text { MADIT-RIT } \\
\text { (Co-PI) }\end{array}$ & None & None & 2.4 .1 \\
\hline Joseph E. Marine & $\begin{array}{l}\text { Johns Hopkins } \\
\text { University } \\
\text {-Associate Professor } \\
\text { of Medicine }\end{array}$ & None & None & None & None & None & None & None \\
\hline Mark H. Schoenfeld & $\begin{array}{l}\text { Yale University School } \\
\text { of Medicine- } \\
\text { Clinical Professor of } \\
\text { Medicine }\end{array}$ & $\begin{array}{l}\text { - United Healthcare- } \\
\text { Advisory Board }\end{array}$ & None & None & None & None & None & 2.4 .1 \\
\hline Amit J. Shanker & $\begin{array}{l}\text { Center for Advanced } \\
\text { Arrhythmia } \\
\text { Medicine-Director } \\
\text { Columbia } \\
\text { University College of } \\
\text { Physicians and } \\
\text { Surgeons-Assistant } \\
\text { Professor of Medicine }\end{array}$ & None & None & None & None & None & None & None \\
\hline Michael J. Silka & $\begin{array}{l}\text { University of Southern } \\
\text { California—Professor } \\
\text { of Pediatrics } \\
\text { Children's Hospital } \\
\text { Los Angeles-- } \\
\text { Chief, Division of } \\
\text { Cardiology }\end{array}$ & None & None & None & None & None & None & None \\
\hline $\begin{array}{l}\text { Lynne Warner } \\
\text { Stevenson }\end{array}$ & $\begin{array}{l}\text { Brigham \& Women's } \\
\text { Hospital—Director, } \\
\text { Cardiomyopathy and } \\
\text { Heart Failure }\end{array}$ & None & None & None & $\begin{array}{l}\text { - Biosense } \\
\text { Websterł }\end{array}$ & None & None & 2.4 .1 \\
\hline $\begin{array}{l}\text { William G. } \\
\text { Stevenson }\end{array}$ & $\begin{array}{l}\text { Brigham \& Women's } \\
\text { Hospital—Director, } \\
\text { Clinical Cardiac EP }\end{array}$ & None & None & None & $\begin{array}{l}\text { - Biosense } \\
\text { Webster } \frac{1}{\dagger}\end{array}$ & None & None & 2.4 .1 \\
\hline Paul D. Varosy & $\begin{array}{l}\text { VA Eastern Colorado } \\
\text { Health Care System- } \\
\text { Director of Cardiac } \\
\text { EP University of } \\
\text { Colorado } \\
\text { Denver-Assistant } \\
\text { Professor of Medicine }\end{array}$ & None & None & None & None & None & None & None \\
\hline
\end{tabular}

This table represents the relationships of committee members with industry and other entities that were determined to be relevant to this document. These relationships were reviewed and updated in conjunction with all meetings and/or conference calls of the writing group during the document development process. The table does not necessarily reflect relationships with industry at the time of publication. A person is deemed to have a significant interest in a business if the interest represents ownership of $\geq 5 \%$ of the voting stock or share of the business entity, or if the interest represents ownership of $\geq \$ 10,000$ of the fair market value of the business entity, or if funds received by the person from the business entity exceed $5 \%$ of the person's gross income for the previous year. Relationships that exist with no financial benefit are also included for the purpose of transparency. Relationships in this table are modest unless otherwise noted. According to the ACCF/AHA, a person has a relevant relationship IF: (a) the relationship or interest relates to the same or similar subject matter, intellectual property or asset, topic, or issue addressed in the document; or (b) the company/entity (with whom the relationship exists) makes a drug, drug class, or device addressed in the document or makes a competing drug or device addressed in the document; or (c) the person or a member of the person's household has a reasonable potential for financial, professional, or other personal gain or loss as a result of the issues or content addressed in the document. DSMB, Data Safety Monitoring Board; EP, electrophysiology; MADIT-RIT, Multicenter Automatic Defibrillator Implantation Trial-Reduce Inappropriate Therapy; PI, principal investigator; VA, Veterans Affairs. *Writing group members are required to recuse themselves from voting on sections to which their specific relationships with industry and other entities may apply. Section numbers pertain to those in the full-text guideline. $\dagger$ Significant relationship. $\ddagger$ No financial benefit. 
APPENDIX 2. Reviewer relationships with industry and other entities (relevant)—2012 ACCF/AHA/HRS focused update of the 2008 guidelines for device-based therapy of cardiac rhythm abnormalities

\begin{tabular}{|c|c|c|c|c|c|c|c|c|c|}
\hline $\begin{array}{c}\text { Peer } \\
\text { reviewer }\end{array}$ & Representation & Employment & Consultant & $\begin{array}{l}\text { Speaker's } \\
\text { bureau }\end{array}$ & $\begin{array}{c}\text { Ownership/ } \\
\text { partnership/ } \\
\text { principal }\end{array}$ & $\begin{array}{l}\text { Personal } \\
\text { research }\end{array}$ & $\begin{array}{c}\text { Institutional, } \\
\text { organizational, or } \\
\text { other financial } \\
\text { benefit }\end{array}$ & & $\begin{array}{l}\text { Expert } \\
\text { witness }\end{array}$ \\
\hline Sana Al-Khatib & $\begin{array}{l}\text { Official Reviewer- } \\
\text { AHA }\end{array}$ & $\begin{array}{l}\text { Duke Clinical } \\
\text { Research Institute } \\
\text { and Duke } \\
\text { University Medical } \\
\text { Center }\end{array}$ & None & - Medtronic & None & None & None & None & \\
\hline Hugh Calkins & $\begin{array}{l}\text { Official Reviewer- } \\
\text { HRS }\end{array}$ & $\begin{array}{l}\text { Johns Hopkins } \\
\text { Hospital }\end{array}$ & $\begin{array}{l}\text { - Biosense } \\
\text { Webster } \\
\text { - Boston } \\
\text { Scientific } \\
\text { - } \text { Medtronic* }\end{array}$ & None & None & $\begin{array}{l}\text { - } \text { Boston } \\
\text { Scientific* } \\
\text { - Medtronic* } \\
\text { - St. Jude } \\
\text { Medical* }\end{array}$ & None & None & \\
\hline $\begin{array}{l}\text { James R. } \\
\text { Edgerton }\end{array}$ & $\begin{array}{l}\text { Official Reviewer- } \\
\text { STS }\end{array}$ & $\begin{array}{l}\text { The Heart Hospital } \\
\text { Baylor Plano }\end{array}$ & None & None & None & None & None & None & \\
\hline $\begin{array}{l}\text { Michael M. } \\
\text { Givertz }\end{array}$ & $\begin{array}{l}\text { Official Reviewer- } \\
\text { HFSA }\end{array}$ & $\begin{array}{l}\text { Brigham and } \\
\text { Women's Hospital }\end{array}$ & None & None & None & None & None & None & \\
\hline $\begin{array}{r}\text { Jonathan L. } \\
\text { Halperin }\end{array}$ & $\begin{array}{l}\text { Official Reviewer- } \\
\text { ACCF/AHA Task } \\
\text { Force on Practice } \\
\text { Guidelines }\end{array}$ & $\begin{array}{l}\text { Mount Sinai Medical } \\
\text { Center }\end{array}$ & - Biotronik* & None & None & None & None & None & \\
\hline $\begin{array}{r}\text { Bradley P. } \\
\text { Knight }\end{array}$ & $\begin{array}{l}\text { Official Reviewer- } \\
\text { HRS }\end{array}$ & $\begin{array}{l}\text { Northwestern } \\
\quad \text { Medical Center }\end{array}$ & $\begin{array}{l}\text { - } \text { Boston } \\
\text { Scientific } \\
\text { - Cameron } \\
\text { Health } \dagger\end{array}$ & $\begin{array}{l}\text { - } \text { Biosense } \\
\text { Webster } \\
\text { - Biotronik } \\
\text { - Boston } \\
\text { Scientific } \\
\text { - } \text { Medtronic }\end{array}$ & None & $\begin{array}{l}\text { - Cameron } \\
\text { Health* }\end{array}$ & None & None & \\
\hline $\begin{array}{l}\text { Thomas J. } \\
\text { Lewandowski }\end{array}$ & $\begin{array}{l}\text { Official Reviewer- } \\
\text { ACCF Board of } \\
\text { Governors }\end{array}$ & $\begin{array}{l}\text { Appleton Cardiology } \\
\text { Thedacare }\end{array}$ & None & None & None & None & None & None & \\
\hline $\begin{array}{l}\text { Henry M. } \\
\text { Spotnitz }\end{array}$ & $\begin{array}{l}\text { Official Reviewer- } \\
\text { AATS }\end{array}$ & Columbia University & None & None & $\begin{array}{l}\text { - Strategic } \\
\quad \text { Pacing } \\
\text { Systems } \dagger\end{array}$ & None & None & None & \\
\hline $\begin{array}{l}\text { C. Michael } \\
\text { Valentine }\end{array}$ & $\begin{array}{l}\text { Official Reviewer- } \\
\text { ACCF Board of } \\
\text { Trustees }\end{array}$ & $\begin{array}{l}\text { The Cardiovascular } \\
\text { Group }\end{array}$ & - Medtronic* & None & None & None & None & None & \\
\hline Paul J. Wang & $\begin{array}{l}\text { Official Reviewer- } \\
\text { AHA }\end{array}$ & $\begin{array}{l}\text { Stanford University } \\
\text { Medical Center }\end{array}$ & - Medtronic & None & None & - Medtronic* & None & None & \\
\hline John F. Beshai & $\begin{array}{l}\text { Content Reviewer- } \\
\text { ACCF EP } \\
\text { Committee }\end{array}$ & $\begin{array}{l}\text { University of Chicago } \\
\text { Medical Center }\end{array}$ & None & None & None & None & $\begin{array}{l}\text { - Medtronic* } \\
\text { - St. Jude } \\
\text { Medical* }\end{array}$ & None & \\
\hline $\begin{array}{l}\text { George H. } \\
\text { Crossley }\end{array}$ & Content Reviewer & St. Thomas Heart & $\begin{array}{l}\text { - Boston } \\
\text { Scientific } \\
\text { - Medtronic }\end{array}$ & $\begin{array}{l}\text { - Boston } \\
\text { Scientific } \\
\text { - Medtronic }\end{array}$ & None & None & $\begin{array}{l}\text { - Boston } \\
\text { Scientific } \\
\text { - Medtronic* }\end{array}$ & None & \\
\hline $\begin{array}{l}\text { Jennifer E. } \\
\text { Cummings }\end{array}$ & $\begin{array}{l}\text { Content Reviewer- } \\
\text { ACCF EP } \\
\text { Committee }\end{array}$ & University of Toledo & None & $\begin{array}{l}\text { - } \text { Boston } \\
\text { Scientific } \\
\text { - Medtronic } \\
\text { - St. Jude }\end{array}$ & None & None & None & None & \\
\hline $\begin{array}{l}\text { Kenneth A. } \\
\text { Ellenbogen }\end{array}$ & Content Reviewer & $\begin{array}{l}\text { Virginia } \\
\text { Commonwealth } \\
\text { University Medical } \\
\text { Center }\end{array}$ & $\begin{array}{l}\text { - Cameron } \\
\text { Health } \\
\text { - Boston } \\
\text { Scientific } \\
\text { - Medtronic }\end{array}$ & $\begin{array}{l}\text { - } \text { Biotronik } \\
\text { - Boston } \\
\text { Scientific } \\
\text { - } \text { Medtronic } \\
\text { - St. Jude } \\
\text { Medical }\end{array}$ & None & None & $\begin{array}{l}\text { - Biosense } \\
\text { Webster* } \\
\text { - Boston } \\
\text { Scientific* } \\
\text { - Medtronic* } \\
\text { - St. Jude } \\
\text { Medical* }\end{array}$ & None & \\
\hline
\end{tabular}


APPENDIX 2. Continued

\begin{tabular}{|c|c|c|c|c|c|c|c|c|}
\hline $\begin{array}{c}\text { Peer } \\
\text { reviewer }\end{array}$ & Representation & Employment & Consultant & $\begin{array}{c}\text { Speaker's } \\
\text { bureau }\end{array}$ & $\begin{array}{c}\text { Ownership/ } \\
\text { partnership/ } \\
\text { principal }\end{array}$ & $\begin{array}{l}\text { Personal } \\
\text { research }\end{array}$ & $\begin{array}{c}\text { Institutional, } \\
\text { organizational, or } \\
\text { other financial } \\
\text { benefit }\end{array}$ & $\begin{array}{l}\text { Expert } \\
\text { witness }\end{array}$ \\
\hline $\begin{array}{l}\text { Roger A. } \\
\text { Freedman }\end{array}$ & Content Reviewer & $\begin{array}{l}\text { University of Utah } \\
\text { Health Sciences } \\
\text { Center }\end{array}$ & $\begin{array}{l}\text { - } \text { Boston } \\
\text { Scientific } \\
\text { - Sorin } \\
\text { - Spectranetics } \\
\text { - St. Jude } \\
\text { Medical }\end{array}$ & None & None & $\begin{array}{l}\text { - } \text { Medtronic** } \\
\text { - St. Jude } \\
\text { Medical* }\end{array}$ & None & $\begin{array}{l}\text { - Defendant, 2011, } \\
\text { pacemaker } \\
\text { battery depletion }\end{array}$ \\
\hline $\begin{array}{l}\text { Gabriel } \\
\text { Gregoratos }\end{array}$ & Content Reviewer & $\begin{array}{l}\text { University of } \\
\text { California- } \\
\text { San Francisco }\end{array}$ & None & None & None & None & None & None \\
\hline David L. Hayes & Content Reviewer & Mayo Clinic & $\begin{array}{l}\text { - Biotronik } \\
\text { - Boston } \\
\text { Scientific } \\
\text { - Medtronic* } \\
\text { - Sorin } \\
\text { - St. Jude } \\
\text { Medical }\end{array}$ & None & None & None & None & None \\
\hline Mark A. Hlatky & Content Reviewer & $\begin{array}{l}\text { Stanford University } \\
\text { School of } \\
\text { Medicine }\end{array}$ & None & None & None & None & None & None \\
\hline Sandeep K. Jain & Content Reviewer & $\begin{array}{l}\text { University of } \\
\text { Pittsburgh } \\
\text { Physicians, UPMC } \\
\text { Heart and Vascular } \\
\text { Institute }\end{array}$ & None & None & None & - Medtronic* & None & None \\
\hline $\begin{array}{l}\text { Samuel O. } \\
\text { Jones }\end{array}$ & Content Reviewer & $\begin{array}{l}\text { San Antonio Military } \\
\text { Medical Center }\end{array}$ & None & None & None & None & $\begin{array}{l}\text { - Medtronic } \dagger \\
\text { - St. Jude Medical } \dagger\end{array}$ & None \\
\hline $\begin{array}{l}\text { Kousik } \\
\text { Krishnan }\end{array}$ & Content Reviewer & $\begin{array}{l}\text { Rush University } \\
\text { Medical Center }\end{array}$ & $\begin{array}{l}\text { - Boston } \\
\text { Scientific } \\
\text { - St. Jude } \\
\text { Medical }\end{array}$ & None & None & None & $\begin{array}{l}\text { - Biotronik* } \\
\text { - Boston Scientific- } \\
\text { MADIT-RIT* } \\
\text { - } \text { Medtronic* }\end{array}$ & None \\
\hline $\begin{array}{l}\text { Michael } \\
\text { Mansour }\end{array}$ & Content Reviewer & $\begin{array}{c}\text { Cardiovascular } \\
\text { Physicians }\end{array}$ & None & None & None & None & None & None \\
\hline $\begin{array}{l}\text { Steven M. } \\
\quad \text { Markowitz }\end{array}$ & $\begin{array}{l}\text { Content Reviewer- } \\
\text { ACCF EP } \\
\text { Committee }\end{array}$ & New York Hospital & $\begin{array}{l}\text { - Biotronik } \\
\text { - Boston } \\
\text { Scientific } \\
\text { - Medtronic } \\
\text { - St. Jude } \\
\text { Medical }\end{array}$ & None & None & None & $\begin{array}{l}\text { - Biosense Webster* } \\
\text { - Boston Scientific* } \\
\text { - Medtronic* } \\
\text { - St. Jude Medical* }\end{array}$ & None \\
\hline $\begin{array}{l}\text { Marco A. } \\
\text { Mercader }\end{array}$ & Content Reviewer & $\begin{array}{l}\text { George Washington } \\
\text { University }\end{array}$ & None & None & None & None & None & None \\
\hline Simone Musco & Content Reviewer & Saint Patrick Hospital & $\begin{array}{l}\text { - Boston } \\
\text { Scientific }\end{array}$ & None & None & None & None & None \\
\hline $\begin{array}{l}\text { L. Kristin } \\
\text { Newby }\end{array}$ & Content Reviewer & $\begin{array}{l}\text { Duke University } \\
\text { Medical Center }\end{array}$ & None & None & None & None & None & None \\
\hline $\begin{array}{l}\text { Brian } \\
\text { Olshansky }\end{array}$ & $\begin{array}{l}\text { Content Reviewer- } \\
\text { ACCF EP } \\
\text { Committee }\end{array}$ & $\begin{array}{l}\text { University of Iowa } \\
\text { Hospitals }\end{array}$ & $\begin{array}{l}\text { - Boston } \\
\text { Scientific } \\
\text { - Guidant } \\
\text { - Medtronic }\end{array}$ & None & None & None & None & None \\
\hline Richard L. Page & Content Reviewer & $\begin{array}{l}\text { University of } \\
\text { Wisconsin } \\
\text { Hospital and } \\
\text { Clinics }\end{array}$ & None & None & None & None & None & None \\
\hline $\begin{array}{l}\text { Allen J. } \\
\text { Solomon }\end{array}$ & Content Reviewer & $\begin{array}{c}\text { Medical Faculty } \\
\text { Associates }\end{array}$ & None & None & None & None & None & None \\
\hline
\end{tabular}


APPENDIX 2. Continued

\begin{tabular}{|c|c|c|c|c|c|c|c|c|}
\hline $\begin{array}{c}\text { Peer } \\
\text { reviewer }\end{array}$ & Representation & Employment & Consultant & $\begin{array}{l}\text { Speaker's } \\
\text { bureau }\end{array}$ & $\begin{array}{c}\text { Ownership/ } \\
\text { partnership/ } \\
\text { principal }\end{array}$ & $\begin{array}{l}\text { Personal } \\
\text { research }\end{array}$ & $\begin{array}{l}\text { Institutional, } \\
\text { organizational, or } \\
\text { other financial } \\
\text { benefit }\end{array}$ & $\begin{array}{l}\text { Expert } \\
\text { witness }\end{array}$ \\
\hline $\begin{array}{l}\text { ohn S. } \\
\text { Strobel }\end{array}$ & Content Reviewer & $\begin{array}{l}\text { Internal Medicine } \\
\text { Associates }\end{array}$ & None & None & None & - Medtronic* & None & None \\
\hline $\begin{array}{l}\text { ephen L. } \\
\text { Winters }\end{array}$ & Content Reviewer & $\begin{array}{l}\text { Morristown Medical } \\
\text { Center }\end{array}$ & $\begin{array}{l}\text { - Biosense } \\
\text { Webster }\end{array}$ & None & None & None & $\begin{array}{l}\text { - Boston Scientific } \\
\text { - Medtronic } \\
\text { - St. Jude Medical }\end{array}$ & $\begin{array}{l}\text { - Defendant, } \\
\text { 2011, complication } \\
\text { of ICD placement }\end{array}$ \\
\hline \multicolumn{9}{|c|}{$\begin{array}{l}\text { This table represents the relationships of reviewers with industry and other entities that were disclosed at the time of peer review and determined to be relevant. It does not nec- } \\
\text { essarily reflect relationships with industry at the time of publication. A person is deemed to have a significant interest in a business if the interest represents ownership of } \geq 5 \% \text { of } \\
\text { the voting stock or share of the business entity, or if the interest represents ownership of } \geq \$ 10,000 \text { of the fair market value of the business entity, or if funds received by the person } \\
\text { from the business entity exceed } 5 \% \text { of the person's gross income for the previous year. A relationship is considered to be modest if it is less than significant under the preceding } \\
\text { definition. Relationships that exist with no financial benefit are also included for the purpose of transparency. Relationships in this table are modest unless otherwise noted. Names } \\
\text { are listed in alphabetical order within each category of review. According to the ACCF/AHA, a person has a relevant relationship IF: (a) the relationship or interest relates to the } \\
\text { same or similar subject matter, intellectual property or asset, topic, or issue addressed in the document; or (b) the company/entity (with whom the relationship exists) makes a drug, } \\
\text { drug class, or device addressed in the document or makes a competing drug or device addressed in the document; or (c) the person or a member of the person's household has } \\
\text { a reasonable potential for financial, professional, or other personal gain or loss as a result of the issues or content addressed in the document. AATS, American Association for } \\
\text { Thoracic Surgery; ACCF, American College of Cardiology Foundation; AHA, American Heart Association; EP, Electrophysiology; HFSA, Heart Failure Society of America; } \\
\text { HRS, Heart Rhythm Society; ICD, implantable cardioverter-defibrillator; MADIT-RIT, Multicenter Automatic Defibrillator Implantation Trial-Reduce Inappropriate Therapy; } \\
\text { STS, Society of Thoracic Surgeons. *Significant relationship. } \dagger \text { No financial benefit. }\end{array}$} \\
\hline
\end{tabular}


APPENDIX 3. Indications for CRT therapy-algorithm

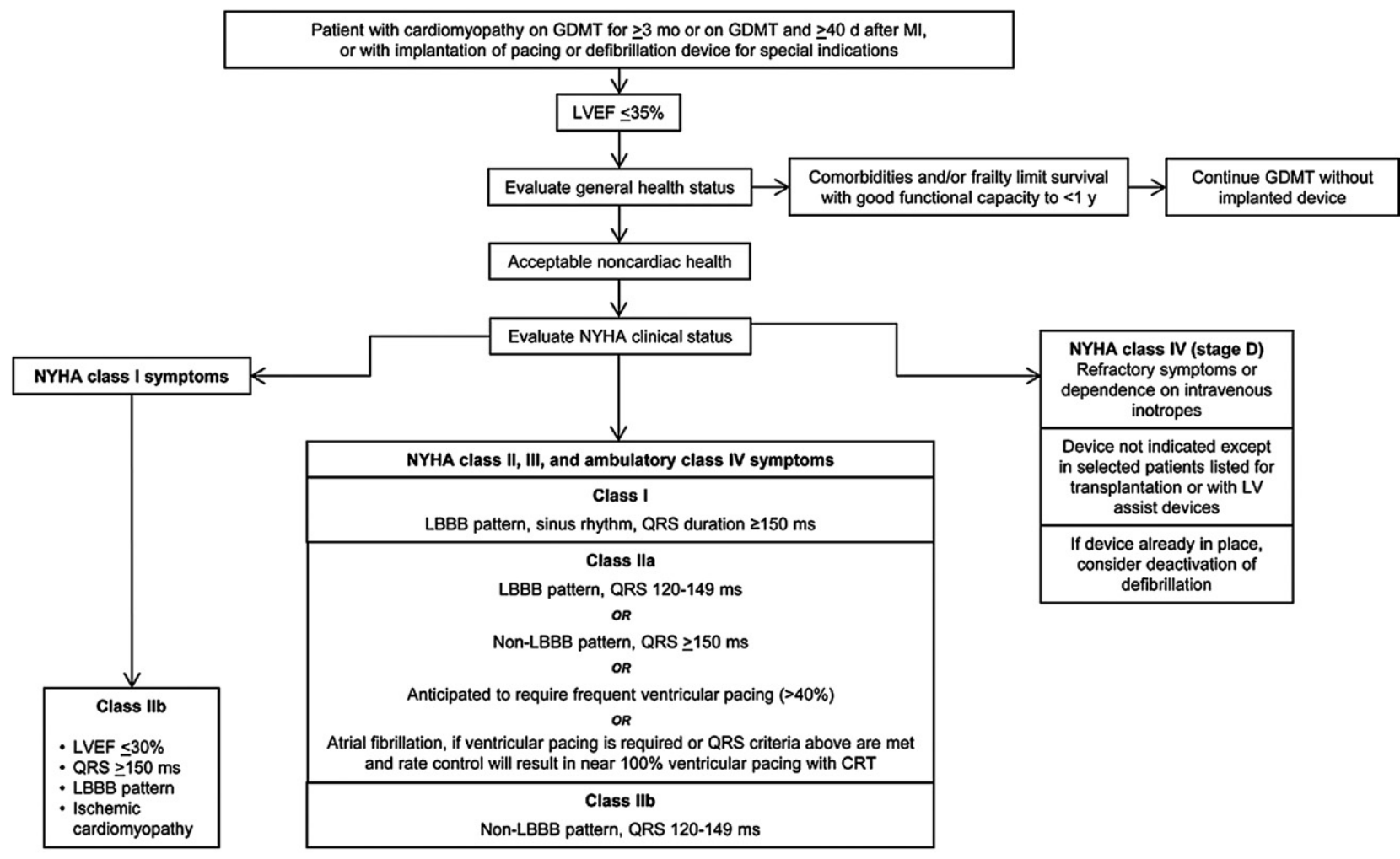

Benefit for NYHA class I and II patients has been shown in CRT-D trials, and while patients may not experience immediate symptomatic benefit, late remodeling may be avoided along with long-term HF consequences. There are no trials that support CRT-pacing (without ICD) in NYHA class I and II patients. Thus, it is anticipated these patients would receive CRT-D unless clinical reasons or personal wishes make CRT-pacing more appropriate. In patients who are NYHA class III and ambulatory class IV, CRT-D may be chosen but clinical reasons and personal wishes may make CRT-pacing appropriate to improve symptoms and quality of life when an ICD is not expected to produce meaningful benefit in survival.

CRT, Cardiac resynchronization therapy; $C R T-D$, cardiac resynchronization therapy defibrillator; $G D M T$, guideline-directed medical therapy; $I C D$, implantable cardioverterdefibrillator; $L V$, left ventricular; $L V E F$, left ventricular ejection fraction; $L B B B$, left bundle-branch block; $M I$, myocardial infarction; and $N Y H A$, New York Heart Association. 